\title{
Prevalence and Risk Factors for Multidrug-Resistant Organisms Colonization in Long-Term Care Facilities Around the World: A Review
}

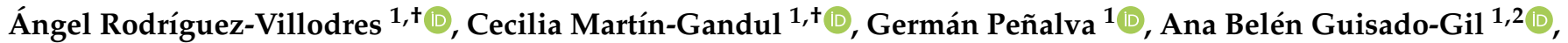 \\ Juan Carlos Crespo-Rivas ${ }^{1}$, María Eugenia Pachón-Ibáñez ${ }^{1} \mathbb{D}$, José Antonio Lepe ${ }^{1}$ and José Miguel Cisneros ${ }^{1, * \mathbb{C}}$
}

Citation: Rodríguez-Villodres, Á.; Martín-Gandul, C.; Peñalva, G.; Guisado-Gil, A.B.; Crespo-Rivas, J.C.; Pachón-Ibáñez, M.E.; Lepe, J.A.; Cisneros, J.M. Prevalence and Risk Factors for Multidrug-Resistant Organisms Colonization in Long-Term Care Facilities Around the World: A Review. Antibiotics 2021, 10, 680. https://doi.org/10.3390/ antibiotics 10060680

Academic Editor: Mamoon Aldeyab

Received: 26 April 2021

Accepted: 2 June 2021

Published: 7 June 2021

Publisher's Note: MDPI stays neutral with regard to jurisdictional claims in published maps and institutional affiliations.

Copyright: (c) 2021 by the authors. Licensee MDPI, Basel, Switzerland. This article is an open access article distributed under the terms and conditions of the Creative Commons Attribution (CC BY) license (https:// creativecommons.org/licenses/by/ $4.0 /)$.
1 Clinical Unit of Infectious Diseases, Microbiology and Preventive Medicine, Institute of Biomedicine of Seville (IBiS), University of Seville/CSIC/University Hospital Virgen del Rocío, 41013 Seville, Spain; anrovi1797@gmail.com (Á.R.-V.); cecilia3778@hotmail.com (C.M.-G.); german.penalva@gmail.com (G.P.); anaguigil@gmail.com (A.B.G.-G.); jccresporivas@gmail.com (J.C.C.-R.); mpachon-ibis@us.es (M.E.P.-I.); josealepe@gmail.com (J.A.L.)

2 Department of Pharmacy, University Hospital Virgen del Rocío, 41013 Seville, Spain

* Correspondence: jmcisnerosh@gmail.com; Tel.: +34-697-958-658

+ Both authors contributed equally to this work.

\begin{abstract}
Elderly people confined to chronic care facilities face an increased risk of acquiring infections by multidrug-resistant organisms (MDROs). This review presents the current knowledge of the prevalence and risk factors for colonization by MDROs in long-term care facilities (LTCF), thereby providing a useful reference to establish objectives for implementing successful antimicrobial stewardship programs (ASPs). We searched in PubMed and Scopus for studies examining the prevalence of MDROs and/or risk factors for the acquisition of MDROs in LTCF. One hundred and thirty-four studies published from 1987 to 2020 were included. The prevalence of MDROs in LTCF varies between the different continents, where Asia reported the highest prevalence of extended-spectrum B-lactamase (ESBL) Enterobacterales (71.6\%), carbapenem resistant (CR) Enterobacterales (6.9\%) and methicillin-resistant Staphylococcus aureus (MRSA) (25.6\%) and North America the highest prevalence to MDR Pseudomonas aeruginosa (5.4\%), MDR Acinetobacter baumannii (15.0\%), vancomycin-resistant Enterococcus spp. (VRE) (4.0\%), and Clostridioides difficile (26.1\%). Furthermore, MDRO prevalence has experienced changes over time, with increases in MDR $P$. aeruginosa and extended spectrum B-lactamase producing Enterobacterales observed starting in 2015 and decreases of CR Enterobacterales, MDR A. baumannii, VRE, MRSA and C. difficile. Several risk factors have been found, such as male sex, chronic wounds, the use of medical devices, and previous antibiotic use. The last of these aspects represents one of the most important modifiable factors for reducing colonization with MDROs through implementing ASPs in LTCF.
\end{abstract}

Keywords: multidrug-resistant organism; long term care facilities; nursing homes; prevalence; risk factors; antimicrobial stewardship

\section{Introduction}

Older adults confined to chronic care facilities are known to have an increased risk of acquiring infections, most commonly those of the skin, soft tissues, respiratory and urinary tracts, as well as gastroenteritis [1]. The recent COVID-19 outbreak has underlined the vulnerability of this group around the world [2], and the condition of frailty is gaining international attention. According to the Organization for Economic Co-operation and Development (OECD), it is expected that the population aged from 65 to 79 years will rise from about 10\% in 2010 to about 15\% in 2050 (https:/ / www.oecd.org/els/healthsystems/47884543.pdf; accessed on 14 December 2020). Thus, current trends in the world's demographic structure indicate increasing requirements in long-term care settings. 
The emergence of multidrug-resistant organisms (MDROs) is a major public health concern [3]. Bacteria such as extended-spectrum ß-lactamase (ESBL) Escherichia coli, ESBL Klebsiella pneumoniae, carbapenem-resistant (CR) Enterobacterales, methicillin-resistant Staphylococcus aureus (MRSA), vancomycin-resistant Enterococcus spp. (VRE), and multidrugresistant (MDR) non-fermenting species such as Pseudomonas aeruginosa and Acinetobacter baumannii are increasing in prevalence [4-7]. Although it is not an MDRO, Clostridioides difficile represents a worldwide public health concern, as it is one of the major causes of antibiotic-associated infections in healthcare settings, especially among older people living in nursing homes (NH) [8,9].

Polypharmacy and inappropriate prescriptions are well-known risk factors for adverse drug reactions, which commonly cause poor clinical outcomes in older people. Antimicrobial resistance is a major negative event resulting from inappropriate prescriptions of antimicrobials [10].

Antimicrobial stewardship programs (ASPs) have been widely implemented in hospitals, with considerable evidence of their impacts on prescription rates and some evidence that they reduce antibiotic-resistant infections [11]. Elderly care facilities and NH could also benefit from these programs. Knowledge of the epidemiology of MDROs at a local and global level is key to implementing successful antimicrobial stewardship intervention. The purpose of this narrative review is to present current knowledge on the prevalence and risk factors for colonization by MDROs in long-term care facilities (LTCF), along with epidemiological data to facilitate the establishment of objectives for implementing successful ASPs in this setting.

\section{Results and Discussion}

\subsection{Studies Included}

Initially, 182 references were selected. Among these references, 48 were excluded as follows: (i) studies that did not include MDROs, NH, or LTCF $(n=18)$; (ii) studies reporting infections by MDROs instead of colonization ( $n=17)$; (iii) limited information about the prevalence of or risk factors for colonization by MDROs $(n=9)$; and (iv) study population duplicated in included studies $(n=4)$. Ultimately, 134 references were included (Figure 1). Studies included in this review were published from 1987 to 2020). The most frequent MDRO analyzed was MRSA $(n=88,65.6 \%)$ [1,12-98] followed by ESBL Enterobacterales $(n=51,38.0 \%)[1,14,16,18-23,25,31,33,34,39,57,62,73,75,76,82,83,85,89,97,99-125](E$. coli and K. pneumoniae), VRE $(n=36,26.8 \%)[1,13,14,18,20-23,25,28,31,33,34,37-39,57-60,64-$ $66,73,74,76,82,83,89,97,106,109,126-129]$, CR Enterobacterales $(n=27,20.1 \%)[1,13,18-22,34$, $60,67,73,82,83,97,100,103,104,108-110,113,118,130-134]$, C. difficile $(n=11,8.2 \%)[19,37,106$, 109,131,135-140], MDR A. baumannii $(n=11,8.2 \%)[13,20,28,37,60,64,67,74,82,85,141]$, and MDR P. aeruginosa $(n=8,5.9 \%)[13,20,34,37,64,67,85,142]$. The types of studies were as follows: 99 (73.8\%) cross-sectional studies $[1,15-17,19,26,28-32,34,35,37,39,40,42-44,46,47,50,52$, $54,55,57,59-62,65,68-73,75,77-85,87-89,91-93,96-109,111,113,116-126,128,129,131-135,137,138$, $140,141,143], 28$ (20.9\%) observational prospective studies [12-14,18,27,33,36,38,41,45,48,51, $53,56,58,66,67,76,90,94,95,110,112,115,127,136,139,144], 3$ (2.2\%) observational retrospective studies $[63,64,114]$, and $4(2.9 \%)$ case-control studies $[74,86,130,142]$. The MDRO samples were isolated from various sources: nasal $(n=79,58.9 \%)[12,14-16,18,34,36,38,40-43,45-75$, $77-88,90-97,99]$, perianal $(n=79,58.9 \%)[12,14,17-23,25,28,29,31-34,38,41,46,47,51,56-60$, 64-67,73-76,78,82,83,85,93,94,99,100,102-106,108-113,115-122,124,126-140,142,144], skin ( $n$ $=33,24.6 \%$ ) $[12,20-24,28,29,32,33,39,41,43,50,54,60,64-66,69,71-74,79,86,87,92,97,99,105,127$, 139], oropharynx $(n=24,17.9 \%)[15,20,21,24,25,29-33,41,47,57,62,64-66,74,83-85,93,113$, 125], ulcers $(n=28,20.9 \%)[12,14,23,29-33,36,41,43,47,51,56,57,63-66,71,74,78,80,81,83,93$, $102]$, urine $(n=15,11.2 \%)[12,14,16,20-22,32,43,80,101,102,104,114,123,124]$, devices $(n=14$, $10.4 \%)[12,18,23,29,30,33,41,64-66,68,80,93,102]$, and sputum $(n=3,2.2 \%)[43,78,141]$.

The studies were conducted in several continents, mainly Europe $(n=70,52.2 \%)[1,13$, 15-22,25,30-32,34,36,37,39,40,46-50,52,53,55,57,62,63,68,70-72,75-77,79,80,83-86,88,91-93,98,99, 101,103-105,107-110,114-121,123,124,136,140], North America $(n=41,30.6 \%)[12,14,23,24,27$, 
29,33,38,41-45,51,58,59,64-66,73,74,78,89,90,94,97,102,109,122,127,129-131,133,134,137-139, 141-144], and Asia ( $n=15,11.2 \%)$ [26,28,35,54,60,67,69,87,95,96,100,111,112,126,132]. Seven studies reported data from Oceania $(5.2 \%)[56,81,82,106,113,125,128]$ and only one from South America (0.7\%) [61]. None of the studies were performed in Africa.

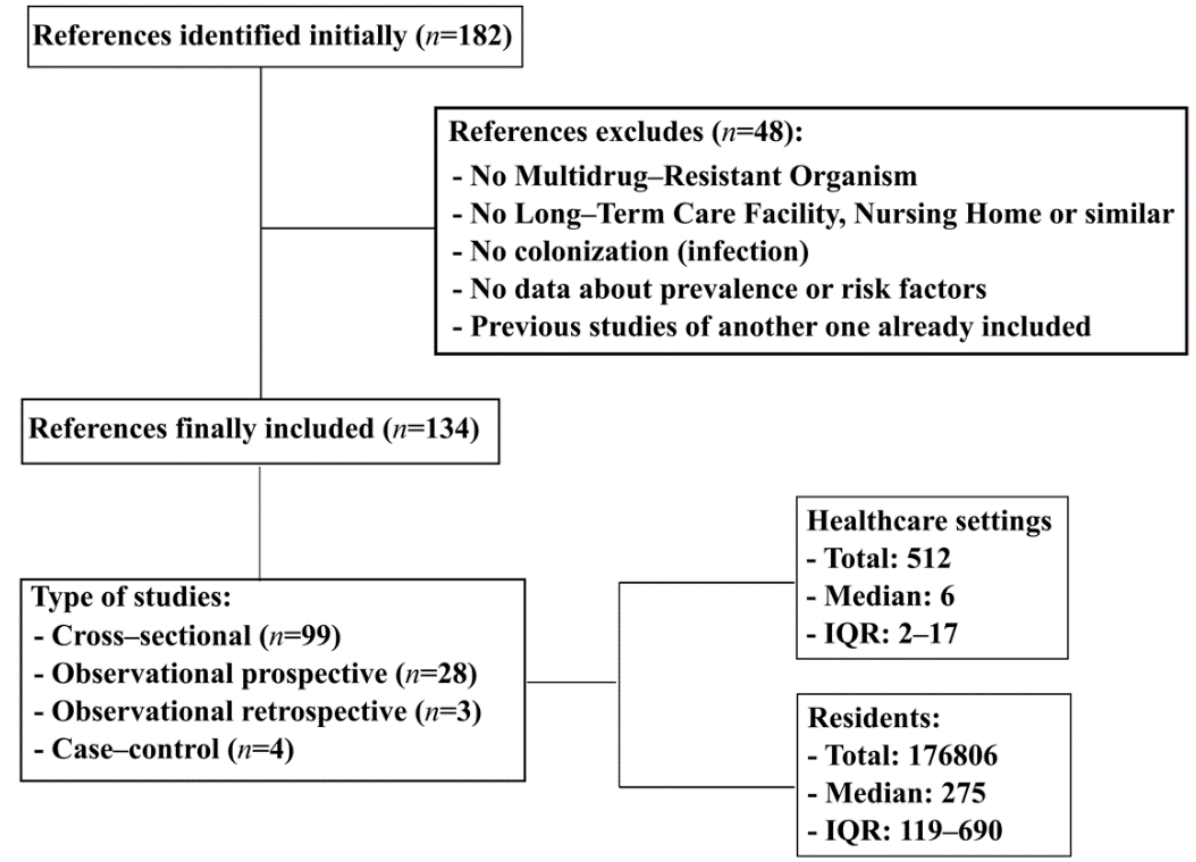

Figure 1. Flowchart search strategy. IQR, interquartile range.

\subsection{MDRO Prevalence}

The overall prevalence of colonization with MDROs around the world varies between the different pathogens studied. For ESBL Enterobacterales, the median prevalence reported was $11.6 \%$, which increased to $15.0 \%$ in the case of ESBL E. coli and decreased to $2.9 \%$ for ESBL K. pneumoniae. The overall prevalence of CR Enterobacterales was $0.8 \%$. Among other MDR Gram-negative bacteria, such as P. aeruginosa and A. baumannii, the prevalences reported globally were $1.3 \%$ and $5.8 \%$, respectively. In the case of Gram-positive bacteria, MRSA showed the highest prevalence at $13.2 \%$, followed by C. difficile $5.1 \%$ and VRE $1.5 \%$ (Table 1).

This prevalence appears to vary between continents. Asia reported the highest prevalence of ESBL Enterobacterales [100,111,112], CR Enterobacterales [60,67,100,132] and MRSA [26,28,35,54,60,67,69,87,95,96]. In contrast, the lowest prevalence of ESBL Enterobacterales, CR Enterobacterales and MRSA have been reported in Oceania [82,106,113,125], Europe [1,13,18-22,34,83,103,104,108-110,118] and South America [61]. With respect to MDR P. aeruginosa [64,142], A. baumannii [64,74,141], VRE [14,23,33,38,58,59,64-66,73,74, 89,97,127,129] and C. difficile [131,137-139], North America reported the highest prevalence. However, remarkably, Asia has the lowest prevalence of VRE [28,60,126] (Table 1, Figure 2). 
Table 1. Prevalence of multidrug-resistant organisms in long term care facilities.

\begin{tabular}{|c|c|c|c|c|c|c|c|c|c|}
\hline $\begin{array}{l}\text { Multidrug-Resistant } \\
\text { Organism }\end{array}$ & $\begin{array}{c}\text { No. of Articles } \\
n=134\end{array}$ & $\begin{array}{c}\text { Percentage of } \\
\text { Articles } n=134(\%)\end{array}$ & $\begin{array}{c}\text { Microorganism } \\
\text { Global Prevalence } \\
n=134 \text { (Median, IQR) }\end{array}$ & $\begin{array}{c}\text { Prevalence in } \\
\text { Europe } n=70 \\
\text { (Median \%, IQR) }\end{array}$ & $\begin{array}{l}\text { Prevalence in North } \\
\text { America } n=41 \\
\text { (Median } \%, \mathrm{IQR} \text { ) }\end{array}$ & $\begin{array}{c}\text { Prevalence in South } \\
\text { America } n=1 \\
\text { (Median } \%, \mathrm{IQR} \text { ) }\end{array}$ & $\begin{array}{c}\text { Prevalence in Asia } \\
n=15 \text { (median \%, } \\
\text { IQR) }\end{array}$ & $\begin{array}{c}\text { Prevalence in } \\
\text { Oceania } n=7 \\
\text { (Median \%, IQR) }\end{array}$ & $\begin{array}{c}\text { Prevalence in Africa } \\
n=0 \text { (Median \%, } \\
\text { IQR) }\end{array}$ \\
\hline ESBL Enterobacterales & 51 & 38.0 & $11.6(5.5-24.5)$ & $12.9(6.3-21.4)$ & $9(3.4-33)$ & - & $71.6(46.6-74)$ & $6.0(1.4-10.8)$ & - \\
\hline ESBL Escherichia coli & 33 & 24.6 & $15.0(7.7-41.4)$ & $15.3(7.8-41.2)$ & $15(2.9-30.3)$ & - & $82.7(50.4-86.1)$ & $10.4(5.6-11.2)$ & - \\
\hline $\begin{array}{l}\text { ESBL Klebsiella } \\
\text { pneumoniae }\end{array}$ & 22 & 16.4 & $2.9(0.4-7.1)$ & $4.2(0.6-6.5)$ & $0.2(0.0-4.8)$ & - & $9.1(8.8-9.4)$ & 1.7 & - \\
\hline $\begin{array}{l}\text { Carbapenem resistant } \\
\text { Enterobacterales }\end{array}$ & 27 & 20.1 & $0.8(0.0-4.2)$ & $0.2(0.0-0.9)$ & $5.0(2.0-7.9)$ & - & $6.9(1.4-14.6)$ & $0.4(0.3-0.5)$ & - \\
\hline $\begin{array}{l}\text { MDR Acinetobacter } \\
\text { baumannii }\end{array}$ & 11 & 8.2 & $5.8(2.2-13.5)$ & $1.9(0-4.3)$ & $15.0(13.5-16.0)$ & - & $5.2(2.9-12.3)$ & 6.0 & - \\
\hline $\begin{array}{l}\text { Meticillin-resistant } \\
\text { Staphylococcus aureus }\end{array}$ & 88 & 65.6 & $13.2(6.6-25)$ & $9.1(4.4-19.6)$ & $22.0(12.0-30.0)$ & 3.7 & $25.6(13-36.8)$ & $10(6.5-13)$ & - \\
\hline $\begin{array}{l}\text { Vancomycin-resistant } \\
\text { Enterococcus spp. }\end{array}$ & 36 & 26.8 & $1.5(0.06-6.9)$ & $0.4(0.0-1.8)$ & $4.0(0.9-20.7)$ & - & $0.0(0.0-4.8)$ & $3.1(2.5-4.5)$ & - \\
\hline Clostridioides difficile & 11 & 8.2 & $5.1(1.9-24.8)$ & $3.7(1.1-4.9)$ & $26.1(16.2-37.5)$ & - & - & 1.0 & - \\
\hline
\end{tabular}

ESBL, extended-spectrum B-lactamase; MDR, multidrug resistant; IQR, interquartile range. 

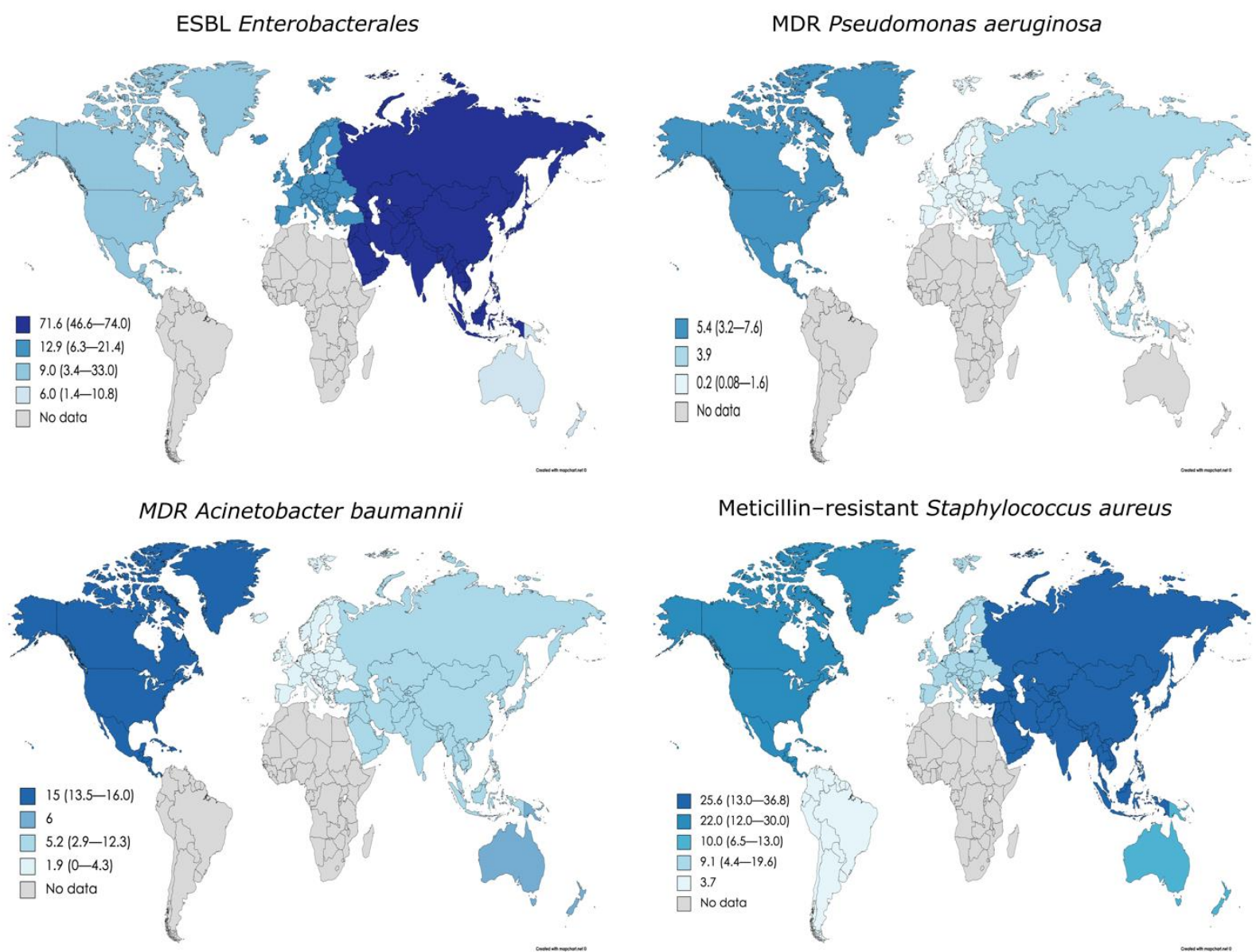

Meticillin-resistant Staphylococcus aureus
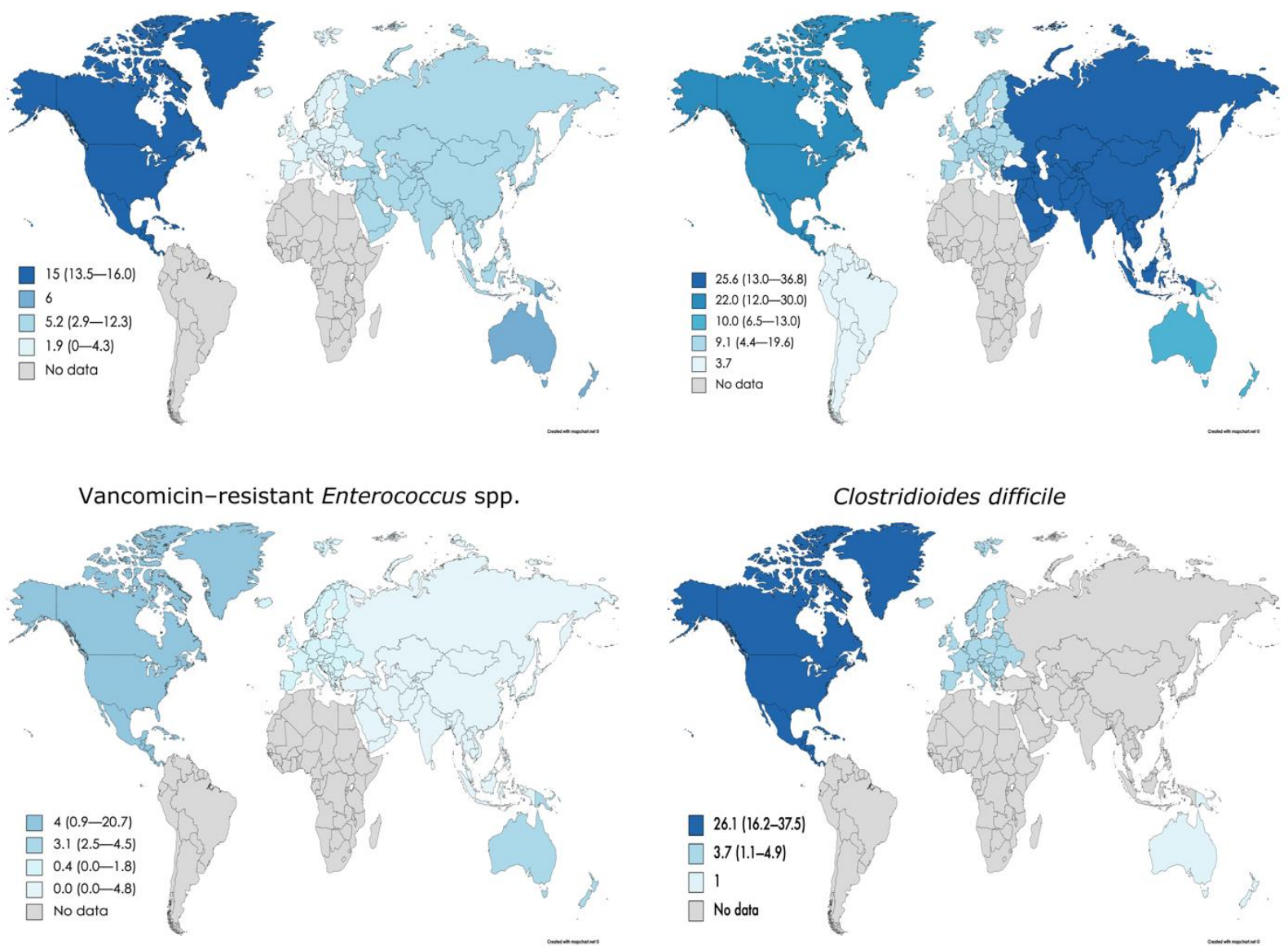

Figure 2. Prevalence of different MDRO in LTCF around the world. Maps were created through the online tool Mapchart.net (https://mapchart.net/world.html, accessed on 23 November 2020). ESBL, extended-spectrum B-lactamase; MDR, multidrug-resistant.

\subsection{MDRO Co-Colonization}

Co-colonization with multiple MDROs seems variable among LTCF. For example, Jans et al. [31] reported a low rate of co-colonization ( $0.8 \%)$ with ESBL Enterobacterales and MRSA among 2791 residents from 60 LTCF. On the other hand, Ludden et al. [18] found that the prevalence of co-colonization with MRSA and ESBL Enterobacterales increased to $39 \%$, although the authors only analyzed one LTCF with 64 residents. Heinze et al. [66] reported that $13.2 \%$ of the residents were co-colonized with both MRSA and VRE. When MDROs were considered, the prevalence of co-colonization ranged from $5.5 \%$ to $21 \%$ for at 
least two MDROs [57,85,142]. All of these studies suggest that LTCF may act as reservoirs for MDROs, through which transmission may occur via resident-resident interactions or resident-healthcare worker interactions.

\subsection{Changes in MDRO Prevalence Over Time}

In the last decade, there has been a remarkable increase in the number of publications on MDR prevalence and LTCF. Figure 3 shows a representation of the median prevalence of MDROs within 5-year periods from 1985 to 2020. In order to be able to observe if there have been changes in the prevalence of MDROs over time, we established a cut-off point in 2015 and compared two time periods (until 2015, including and after 2015). Thus, we had a balanced number of publications on both groups, for each MDRO (Table 2). The ESBL Enterobacterales prevalence increased from 10.5\% [14,18,22,23,25,31,33,39,57,75,76,82,85, $89,99,101,102,104,106,107,111,112,116,119,121-125,143]$ to $15.1 \%[1,16,19-21,34,62,73,83,97$, $100,103,105,108-110,113-115,117,118,120]$, but this increase seems to be due to ESBL K. pneumoniae $(0.7 \%$ vs. $4.2 \%)$ rather than ESBL E. coli ( $18.0 \%$ vs. $14.4 \%)$. In contrast, the prevalence of CR Enterobacterales decreased from 2015 onward (2.9\% vs. $0.8 \%)[18,22,82,104,132,133]$ vs. $[1,13,19-21,34,60,67,73,83,97,100,103,108-110,113,118,130,131,134]$, as did that of MDR A. baumannii, from $10.5 \%$ to $5.2 \%$ [ $74,82,85,141]$ vs. $[13,20,28,37,60,64,67]$; that of VRE, from $2.8 \%$ to $0.6 \%[14,18,22,23,25,31,33,38,39,57-59,65,74,76,82,89,106,126-129]$ vs. $[1,13,20,21,28$, $34,37,60,64,66,73,83,97,109]$; that of MRSA, from $16.0 \%$ to $9.6 \%[14,17,18,22,23,25-27,29-$ $33,35,36,38-48,50,54,56-59,63,65,68,69,71,72,75-81,84-86,89-91,93-96,98]$ vs. $[1,13,15,16,19-$ $21,24,28,34,37,49,55,60-62,64,66,67,70,73,83,87,88,92,97] ;$ and that of C. difficile, from $7.1 \%$ to $3.9 \%[106,137-140]$ vs. $[19,37,109,131,135,136]$. Conversely, the prevalence of MDR P. aeruginosa experienced a slight increase in recent years $(0.5 \%$ vs. $2.75 \%)[85,142]$ vs. [13,20,34,37,64,67] (Table 2). At a more individual level, Kohler et al. [13] analyzed changes in the prevalence of MDROs between 2007 and 2017 in NH from Switzerland. The authors reported an increase from $1.6 \%$ to $7.8 \%$ in ESBL K. pneumoniae and from $2 \%$ to $8 \%$ in MDR P. aeruginosa. Furthermore, a decrease from $34.3 \%$ to $25.9 \%$ was observed in MRSA prevalence. However, in contrast with the global data from this review, ESBL E. coli showed an increase from $5.4 \%$ in 2007 to $21.6 \%$ in 2017. Min et al. [33], in a one-year period of study, also reported an increase in the prevalence of ESBL-Enterobacterales from $36 \%$ to $39 \%$ and of VRE, from $10 \%$ to $13 \%$. However, in contrast with the previous study, they observed an increase in the prevalence of MRSA, from $23 \%$ to $43 \%$.

Table 2. Changes in the prevalence of multidrug-resistant organisms, before and after 2015.

\begin{tabular}{|c|c|c|c|c|c|}
\hline $\begin{array}{l}\text { Multidrug-Resistant } \\
\text { Organism }\end{array}$ & $\begin{array}{c}\text { No. of Articles } \\
\text { (2015 or Before) } n=90\end{array}$ & $\begin{array}{c}\text { No. of Articles } \\
\text { (After 2015) } n=44\end{array}$ & $\begin{array}{l}\text { Prevalence of MDR } \\
\text { (2015 or Before) } \\
\text { Median (IQR) }\end{array}$ & $\begin{array}{c}\text { Prevalence of MDR } \\
\text { (After 2015) Median } \\
\text { (IQR) }\end{array}$ & $\begin{array}{c}\text { Difference } \\
(\%)\end{array}$ \\
\hline ESBL Enterobacterales & 30 & 22 & $10.5(3.5-31.4)$ & $15.1(9.1-19.9)$ & 4.6 \\
\hline ESBL Escherichia coli & 19 & 14 & $18.0(5.5-40.9)$ & $14.4(8.1-41.4)$ & -3.6 \\
\hline ESBL Klebsiella pneumoniae & 10 & 12 & $0.7(0.2-9.2)$ & $4.2(0.7-6.3)$ & 3.5 \\
\hline $\begin{array}{c}\text { Carbapenem resistant } \\
\text { Enterobacterales }\end{array}$ & 6 & 21 & $2.9(0.1-7.5)$ & $0.8(0-1.9)$ & -2.1 \\
\hline MDR Pseudomonas aeruginosa & 2 & 6 & $0.5(0.25-0.75)$ & $2.75(0.5-8.2)$ & 2.25 \\
\hline MDR Acinetobacter baumannii & 4 & 7 & $10.5(5.4-15.5)$ & $5.2(0.3-8.9)$ & -5.3 \\
\hline $\begin{array}{l}\text { Meticillin-resistant } \\
\text { Staphylococcus aureus }\end{array}$ & 61 & 26 & $16.0(7.8-23.3)$ & $9.6(3.9-25.5)$ & -6.4 \\
\hline $\begin{array}{l}\text { Vancomycin-resistant } \\
\text { Enterococcus spp. }\end{array}$ & 22 & 14 & $2.8(0.5-5.5)$ & $0.6(0.001-13.0)$ & -2.2 \\
\hline Clostridioides difficile & 5 & 6 & $7.1(4.6-33.0)$ & $3.9(1.1-15.7)$ & -3.2 \\
\hline
\end{tabular}

IQR, interquartile range; ESBL, extended-spectrum ß-lactamase; MDR, multidrug resistant. 
ESBL Enterobacterales

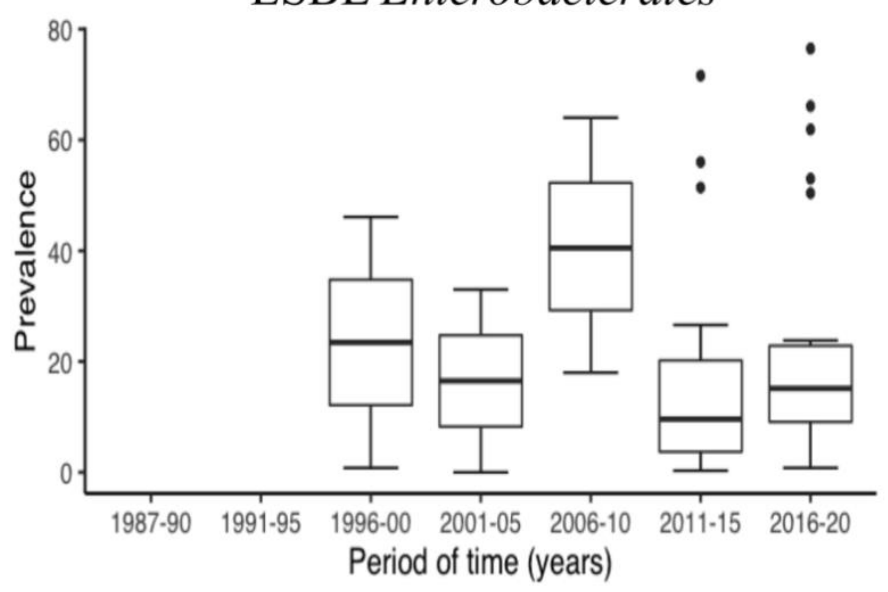

MDR Acinetobacter baumannii

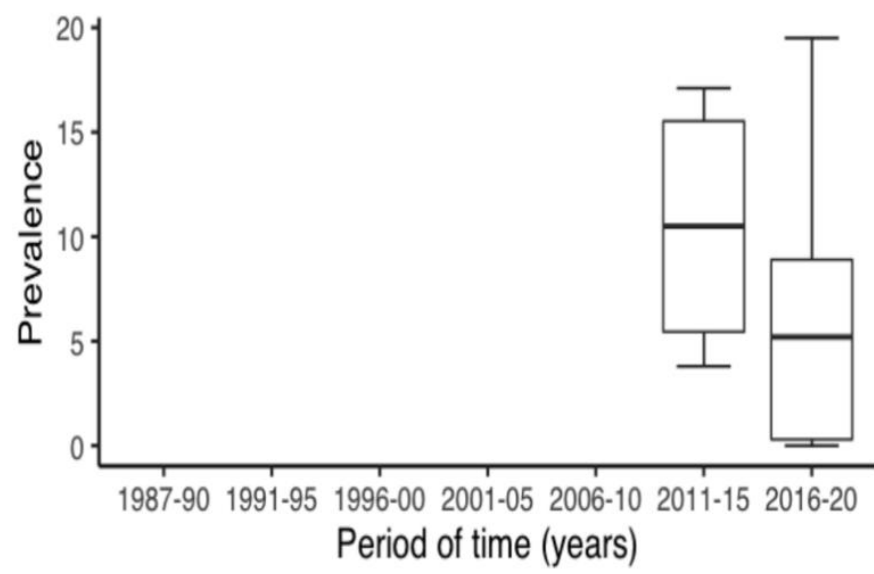

Vancomycin-resistant Enterococcus

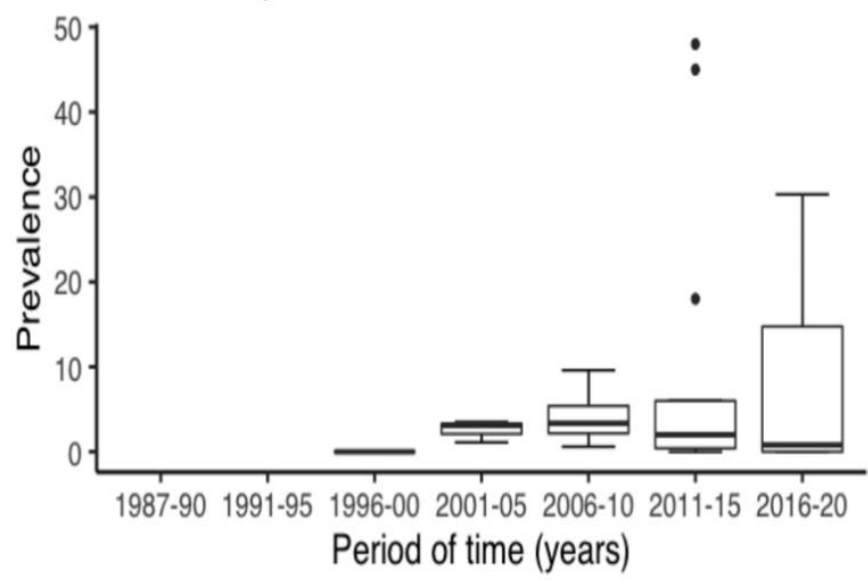

MDR Pseudomonas aeruginosa

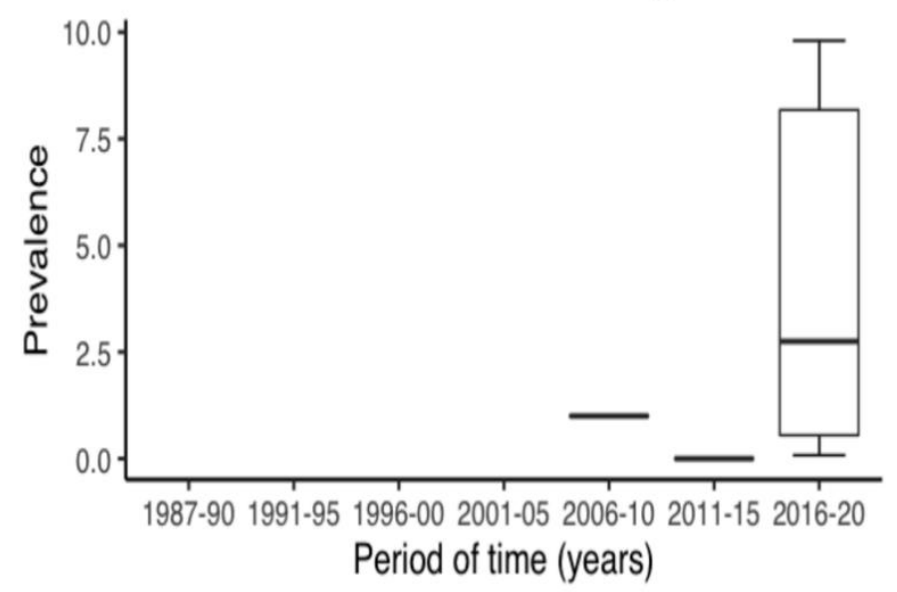

MRSA

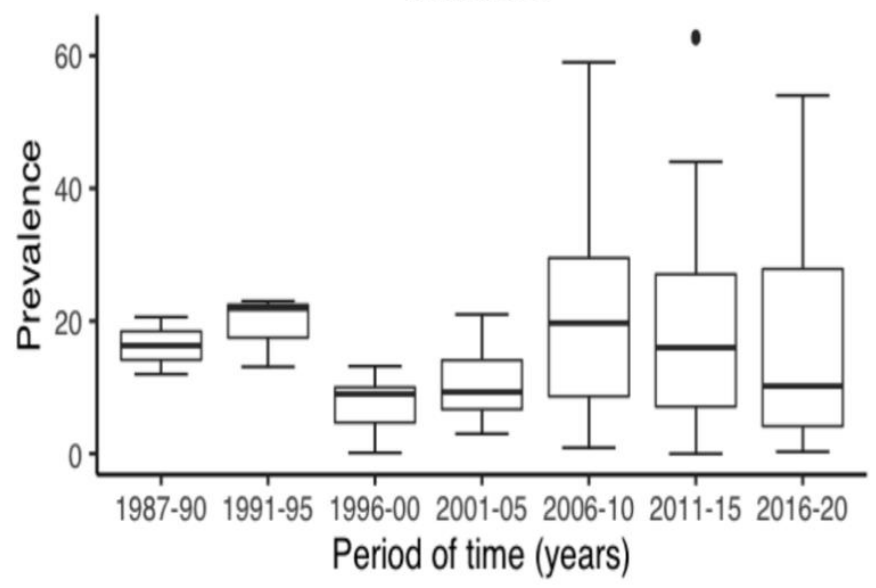

Clostridioides difficile

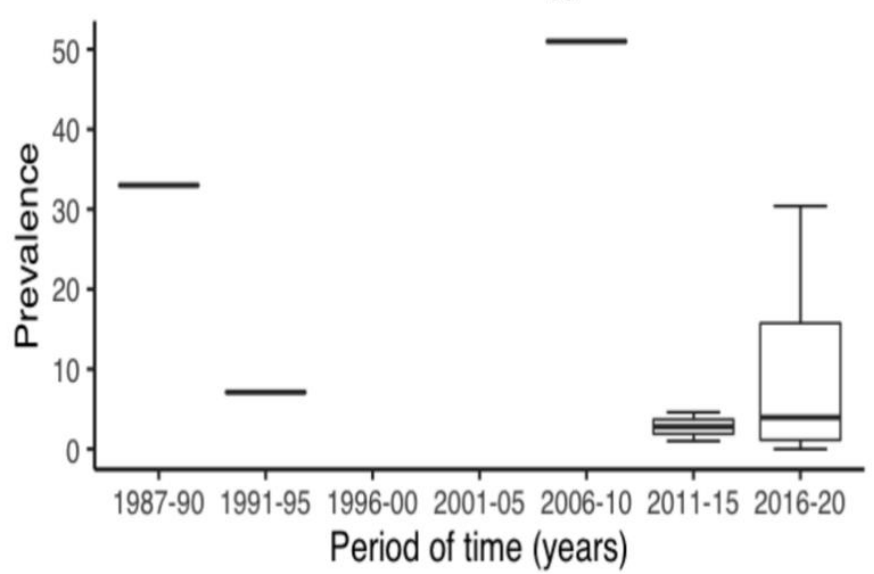

Figure 3. Prevalence of different MDRO in LTCF in 5-year periods. ESBL, extended-spectrum B-lactamase; MDR, multidrugresistant; MRSA, methicillin-resistant Staphylococcus aureus.

\subsection{Risk Factors for Colonization}

2.5.1. Reside in Nursing Homes

Residing in $\mathrm{NH}$ and other LTCF was reported in many studies to be a risk factor for MDRO colonization $[28,37,99]$. A point-prevalence study analyzing MDRO prevalence in 
LTCF, rehabilitation clinics, and homecare facilities found that LTCF and homecare services correlated with a much higher prevalence of MDROs and C. difficile than rehabilitation clinics [37]. In a prospective study performed in France to identify and compare residents of NH or LTCF colonized with bacteria (defined as exposure to the risk of carrying MDROs) with those living at home (defined as non-exposed), the rate of MDRO carriage was found to be three times higher among institutionalized patients [99].

In a cross-sectional study conducted in a 342-bed hospital and 4 LTCF in Spain, at hospital admission, the prevalence of MRSA colonization was found to be around five times more likely (odds ratio (OR) 4.84 95\% CI 1.00-23.51) among patients referred from an LTCF or residential center than among patients from the community [72]. In Singapore, the admission prevalence of MRSA colonization was $41 \%(78 / 190)$ for those from NH and 6.0\% (885/14,849) among non-nursing home residents (relative risk (RR) 6.89 95\% CI 5.74-8.26). In this study, the fraction of the MRSA burden upon admission attributable to $\mathrm{NH}$ residency was $6.92 \%$ [35]. In a German study, the prevalence of intestinal colonization by C. difficile among $240 \mathrm{NH}$ residents was higher than that among 249 volunteers living outside the LTCF ( $4.6 \%$ vs. $0.8 \%, p=0.02)$ [140].

Thus, residing in LTCF seems by itself to be a risk factor for colonization by MDROs. However, differences in NH infrastructure need to be considered. Specifically, the presence of communal areas and multi-bed resident rooms could impact the transmission risk inside such areas [109].

\subsubsection{Age}

Older age was also established in many studies as a risk factor for MRSA colonization based on bivariate analysis $[13,20,26,61,79,98]$. In most studies, age was analyzed as a categorical variable. An analysis of national surveillance data over an 11-year period between 2007 and 2017 in Swiss NH, including a total of 9940 residents, established three categories $(<70,70-85$, and $>85)$ that increased the colonization risk from age 70 onward [13]. Similar results were obtained in Ireland for residents $>80$ years [98] and in four Italian LTCF fixing the cut-off at $>86$ years [20]. However, in these studies, the rates reported as an increased risk of MDRO colonization were two-fold lower and lacked statistical significance in the multivariate analysis.

Some studies reported age as an independent risk factor via multivariate analysis $[22,26,80]$. In Northern Ireland, a point-prevalence study of $45 \mathrm{NH}$ including 1111 residents, based on a reference age of $<60$ years, found that those aged $\geq 90$ were around nine times more likely to be colonized in the adjusted analysis (OR 8.77 95\% CI 2.86-26.86; $p<0.001$ ) [80]. An Italian study reported OR $4.63(95 \%$ CI $1.12-19.1 ; p=0.034)$ in residents with age $\geq 86$ years to be colonized by ESBL producers [22], and in Taiwan, MRSA colonization was more frequent in residents aged $\geq 60$ years (OR $2.16495 \%$ CI1.168-4.001; $p=0.013$ ) [26].

No difference was established by age as a continuous variable in a study including $14 \mathrm{NH}$ in Taiwan; however, an age $>60$ years was significantly associated with MRSA colonization (OR 2.164 95\% CI 1.168-4.011) [26]. An age $\geq 86$ years was related to ESBL colonization, but not to MRSA colonization in a point-prevalence study of MRSA, VRE, ESBL Enterobacterales, CR, and high-level AmpC activity in a 120-bed LTCF attached to the regional hospital in Bolzano, Italy [22].

Therefore, older patients were generally around twice as likely to be colonized than younger patients across the studies; however, some studies found no differences up to 90 years of age based on multivariate analysis. In addition, the different categories used in the studies prevent us from establishing a cut-off or fixed age that is more likely to be colonized by MDROs (Table 3). 
Table 3. Risk factors for multidrug-resistant organism colonization in long-term care facilities in the studies. Common characteristics and limitations.

\begin{tabular}{|c|c|}
\hline Risk Factors for MDRO Colonization & Limitations and Common Characteristics \\
\hline Age & $\begin{array}{c}\text { An increase entails higher risk. There is not a cut-off established for colonization } \\
\text { by MDROs. }\end{array}$ \\
\hline Male sex & Confirmed in many studies by multivariate analysis \\
\hline Dementia & $\begin{array}{c}\text { An increase entails higher risk. There is not a cut-off established for colonization } \\
\text { by MDROs. }\end{array}$ \\
\hline Diabetes & Controversial results. Differences by MDRO type. \\
\hline Cancer & Controversial results. Differences by MDRO type. \\
\hline Chronic wound & Confirmed in many studies by multivariate analysis \\
\hline Dependence & $\begin{array}{c}\text { An increase entails higher risk. There is not a cut-off established for colonization } \\
\text { by MDROs. }\end{array}$ \\
\hline Medical devices & Confirmed in many studies by multivariate analysis \\
\hline Previous antibiotic use & Confirmed in many studies by multivariate analysis \\
\hline Previous hospitalization & Whether the risk could be increased by days of hospitalization is unknown. \\
\hline Previous MDRO colonization & Controversial results. Differences by MDRO type. \\
\hline
\end{tabular}

MDRO: multidrug-resistant organism.

\subsubsection{Sex}

The risk of MDRO colonization was higher in males than in females across the studies $[13,20,31,43,47,49,77,98]$ (Table 3). An Italian point-prevalence study of 340 residents in four LTCF found male sex to be an independent risk factor for MRSA colonization with an OR of 2.31 (95\% CI 1.16-4.59); however, male sex was not found to be an independent risk factor for ESBL colonization in this study [20]. In Ireland, a study including $6 \mathrm{NH}$ and 786 residents obtained similar results for MRSA colonization, with an OR 2.18 95\% CI (1.28-3.73) [98]. Other studies reported male sex to be around 1.5 times more likely than the female sex to be colonized by MRSA $[77,80]$.

In Belgium, a multilevel logistic regression analysis of individual risk factors for ESBL Enterobacterales carriage among 2457 residents of $60 \mathrm{NH}$ determined an OR of 1.5 (95\% CI 1.1-2.1) associated with the male sex [31]. Other authors found similar results for ESBL colonization in Switzerland [13].

The reason why male sex is a risk factor remains unknown. However, the higher frequencies of other risk factors among male residents, who have more co-morbidities compared to female residents, likely predisposed men to have around 1.5 times greater risk than women for MDRO acquisition in most studies.

2.5.4. Underlying Diseases: Dementia (Lower Cognitive Status), Diabetes, Cancer and Chronic Wound (Pressure/Decubitus Ulcer)

Analyzing the impact of underlying diseases on MDRO colonization is not a straightforward task, since miscellaneous baseline diseases are included in many studies, which makes it challenging to draw conclusions. In some studies, underlying diseases were ranked using the Charlson index or co-morbidity score [74,79]. Residents with a Charlson index of $\geq 2$ were 1.5 times more probable to be colonized by MRSA in a study performed on two communities in Spain, including nine LTCF with a total of 1586 beds [79].

In the same way, some studies analyzed diseases such as dementia as encased variables within chronic cerebral conditions to rank their Global Deterioration Score (ranging from 0 -normal to 7 -end-stage dementia) $[28,58,96]$. Two studies in Hong Kong found dementia, encased with other chronic cerebral conditions such as cerebrovascular accidents and Parkinson's disease, to be independent risk factors for MRSA colonization based on multivariate analysis $[28,96]$. Other studies included the level of dementia, categorized 
as dementia or advanced dementia, or referred to low cognitive status. A cross-sectional study performed in four nursing units in a 648-bed LTCF in Boston (USA) identified advanced dementia, but not dementia as a risk factor for MDR Gram-negative bacteria colonization [59].

In addition to dementia, cancer and diabetes were evaluated as possible risk factors for MDRO colonization in many studies [17,20,66,74,112]. Diabetes was found to be an independent risk factor for MDR A. baumannii colonization in residents with an indwelling device (urinary catheter and/or feeding tube) in a nested case-control study within a multicenter prospective intervention trial in the USA [74]. Other authors found diabetes to be an independent predictor of co-colonization by MRSA and VRE [66], as well as ESBL colonization [112]. However, there is no strong evidence for the association between diabetes and MDRO colonization, since other studies found no supporting information for diabetes as an independent risk factor for MDRO colonization based on multivariate analysis $[28,60]$. This is also the case for cancer. A point-prevalence survey in two LTCF with 551 residents in Italy established that the risk of MRSA carriage was increased by six times in patients with cancer [17]. However, cancer was found to be an independent risk factor for ESBL colonization, but not for MRSA colonization in another Italian pointprevalence study performed in four LTCF, including 340 residents [20]. In Hong Kong, a study including 1408 residents from $28 \mathrm{NH}$ determined an increased risk among cancer patients for CR A. baumannii colonization, but not for MRSA colonization in a bivariate analysis [28]. Dementia, diabetes mellitus, and cancer are the most frequent underlying diseases analyzed in relation to the risk of MDRO colonization across the various studies. However, chronic wounds (or pressure/decubitus ulcers) showed the clearest relationship to MDRO colonization $[57,82]$. The presence of chronic wounds is the principal baseline condition evaluated in MRSA colonization studies [28,31,43,51,79,99], and strong evidence has shown chronic wounds to be an independent risk factor for MRSA colonization, increasing the risk by around two times in studies performed in Spain, Belgium, and the USA $[31,43,79]$. In addition to MRSA colonization, studies have reported decubitus ulcers to be an independent risk factor for VRE colonization $[97,127]$, as well as MRSA and VRE co-colonization [66].

In short, the presence of wounds is one of the principal underlying conditions related to MDRO colonization across the studies, mainly in MRSA studies. On the other hand, the information is controversial for diabetes and cancer. There is stronger evidence supporting dementia. However, like age, no cut-off dementia level has been established for colonization by MDROs. Generally, when the severity of illness or fragility increased the odds of MDROs, colonization also increased $[43,66]$ (Table 3).

\subsubsection{Dependence or Disability}

Lower functional status has been independently associated with MDRO colonization in many studies [18-20,22,28,30,31,57,62,65,74,83,97,112] (Table 3). However, similar to age and dementia, establishing a level of dependence for the probability of MDRO colonization is difficult - in this case, due to the variability of the scores used across the studies. Some studies described functional status according to the Katz Index of Independence in Activities of Daily Living (ADL) and the Physical Self-Maintenance Score (PSMS), with a score of 6 indicating total dependence in six major daily activities (i.e., bathing, dressing, using the toilet, transferring, continence, and feeding) [58,59,82]. A nested case control study within a multicenter prospective intervention trial including 168 residents (25 cases vs. 143 controls) in the USA found that residents with a PSMS score $>24$ were associated with a 5.1 times greater likelihood (95\% CI 1.8-14.9) of MDR A. baumannii colonization [74].

Another score frequently used is the Barthel index, which ranges from total dependence ( $<20$ points) to independence (100 points), usually represented as percentage $[22,72,79,85]$. In an Italian study, the most significant risk factor for MRSA and ESBL producers and all resistant bacteria among LTCF residents was chronic immobility, based on a Barthel index score of 0 [22]. Another mobility index is the Karnofsky index, which is 
often used to evaluate the functional status in LTCF $[99,127]$ and is useful as a mortality predictor. A Karnofsky index of $\leq 50 \%$ indicates a higher mortality risk in the following six months and means that the resident is bedridden for at least $50 \%$ of the day. A Karnofsky index of $\leq 50 \%$ was the only risk factor that enhanced the institutionalized carrier rate in a prospective study conducted in France to identify and compare the residents of $\mathrm{NH}$ and LTCF (defined as exposure to the risk of carrying MDROs) with those living at home (defined as non-exposed) [99]. Some studies used a French index known as GIR to evaluate the level of dependency (varying from 1 to 6 , with an index close to 1 indicating a high level of dependency) $[46,118]$. A GIR score of $<3$, corresponding to severe disabilities, was associated with MRSA carriage in a prevalence study performed in a 120-bed LTCF containing three units and belonging to a French teaching hospital [46].

Apart from the index, dependence categories among studies include autonomous mobility vs. non-autonomous vs. bedridden [19]; ambulant (with or without help) vs. bedridden [31,83,105]; and ranking the dependence level as low, medium, or high [91].

Despite the lack of a dependence level cut-off related to MDRO colonization, there is seemingly compelling evidence to indicate than an increase in the level of dependence is associated with an increase in the risk to be colonized by MDROs.

2.5.6. Medical Devices: Indwelling or Invasive Devices, Urinary Catheters, and Gastrointestinal Tubes (Feeding or Percutaneous Enteral Gastrostomy Tubes)

Medical devices, feeding/percutaneous enteral gastrostomy (PEG) tubes, and urinary catheters are considered primary potential risk factors across the studies for all MDROs [82] (Table 3). In an Australian point-prevalence study of four co-located LTCF, including 115 residents, the presence of medical devices was observed to be an independent risk factor for MDRO colonization, with an OR of 5.58 (95\% CI 1.34-23.32) [82]. Specifically, for MRSA colonization, indwelling or invasive devices increased the risk by around three times among the 443 residents in the seven NH in China [87]. Similar results were obtained in a Spanish study, including nine LTCF [79] and in a cross-sectional prevalence survey of 708 residents from 39 care homes in the United Kingdom [77]. Patients with indwelling devices in place were 5.5 times as likely as those without devices to suffer MRSA and VRE co-colonization (95\% CI: 2.2-13.7) [66].

In some studies, differences were noted in the types of medical devices (nasogastric tubes, PEG tubes, tracheostomy tubes, and urinary catheters) in relation to ESBL or MRSA colonization based on bivariate analysis $[20,22,97]$. However, these differences were neither uniform across the studies, nor in the multivariate analyses. The presence of urinary catheters was found to be an independent risk factor for MRSA and VRE, but not ESBL colonization in a serial point-prevalence study (based on six point-prevalence samples of 50 residents, each for at least two weeks) at three $\mathrm{NH}$ in southern California (USA) [97]. However, other studies reported urinary catheters to be an independent risk factor for ESBL but not for MRSA colonization [20,57]. Gastrointestinal devices have been associated with an increased risk of MRSA, ESBL, and CR Enterobacterales, as well as CR A. baumannii colonization, in different studies $[28,73,102,109]$. Other devices like ventilators were found to be independent risk factors for CR A. baumannii and CR Enterobacterales colonization [132,141].

The presence of medical devices, regardless of the type of devices or MDROs, was found to be a common risk factor for MDRO colonization across the studies. Mody et al. designed a multimodal-targeted infection program to reduce the prevalence of MDRO device-related infections. The Targeted Infection Program included the following: (1) preemptive barrier precautions; (2) active surveillance for MDROs and infections with data feedback; and (3) NH staff education on key infection prevention practices, as well as the promotion of good hand hygiene. The results of this randomized clinical trial showed a $23 \%$ reduction in MDRO prevalence, including MRSA, VRE, and Gram-negative bacteria resistant to either ciprofloxacin or ceftazidime in the intervention group [145]. 


\subsubsection{Antibiotics Use in the Preceding Months}

In a large observational study conducted in north-eastern France, resistance to amoxicillin/clavulanate, fluoroquinolones, and ceftriaxone from Enterobacterales (E. coli, Proteus mirabilis, and K. pneumoniae) cultured from urine samples collected in 2014-17 was around $40 \%$ higher among the $\mathrm{NH}$ residents than among older adults living in the community [114].

Antibiotic consumption is the main modifiable factor necessary to avoid an exponential increase in antimicrobial resistance. Wang et al. described the influence network comprising antibiotic treatment, MDRO colonization, and infection by leveraging active surveillance and antibiotic treatment data for $234 \mathrm{NH}$ residents and demonstrated the importance of designing strategies that account for a complex set of inter-dependencies among different MDROs and the antibiotics that influence their spread [64]. Thus, ecological antibiotic prescriptions must come first. Fluoroquinolone use has been reported to be an independent risk factor for MDRO colonization in multiple studies [20,30,38,83,84,116]. Importantly, ASPs would help encourage the correct use of antibiotics. In the Netherlands, a study in $64 \mathrm{LTCF}$ with at least 50 beds (excluding rehabilitation) determined higher consumption (each extra $50 \mathrm{DDD} / 1000$ residents/day nearly doubled carriage) as the strongest predictor of ESBL E. coli carriage based on multilevel multivariable logistic regression (OR $1.8,95 \%$ CI 1.1-3.0) [16]. In Northern Ireland, residents who were found to carry MDR E. coli were more likely to have been prescribed fluoroquinolones or trimethoprim. In this study, the number of days of fluoroquinolone use was found to be an independent risk factor for MDR E. coli colonization (OR 1.33, 95\% CI 1.04-1.69) [116].

Previous antibiotic use has also been reported to be a risk factor for MDRO colonization $[22,31,35,79,126]$ (Table 3). Specifically, exposure to amoxicillin/clavulanate or fluoroquinolones was the most frequent factor analyzed, since these are broad-spectrum antibiotics $[1,30]$. The use of $ß$-lactam/ $\beta$-lactamase inhibitors in the preceding six months was also found to be an independent risk factor for MRSA colonization (OR 2.34 95\% CI 1.44-3.82) in a study of 2322 subjects from $28 \mathrm{NH}$ in the Hong Kong west district [28]. Documented or probable antibiotic use in the 60 days before admission was correlated with VRE colonization (OR 4.2 95\% CI 1.4-12.5; $p=0.008$ ) in hospitalized residents of the Rush-Presbyterian-St. Luke's Medical Center in Chicago (USA) [127].

C. difficile is not defined as an MDRO; however, C. difficile was included in this review due to its impact on healthcare management in LTCF, specifically as a result of inappropriate antibiotic use. A meta-analysis on the prevalence of and risk factors for asymptomatic carriers of toxigenic $C$. difficile in LTCF determined that antimicrobial use in the previous three months was associated with around a four-times greater risk of being colonized [146].

\subsubsection{Hospital Admission in the Previous 12 Months, Any Department}

In studies performed in Belgian and American NH, hospital admission in the previous 12 months increased the risk of MRSA colonization by up to four times [36,83]. A Belgian study including 2953 residents of 60 highly skilled NH observed around a two-times greater risk of MRSA and ESBL colonization among residents who were hospitalized in the previous 12 months [30]. For MRSA colonization, this risk increased by up to nine times in a Brazilian study analyzing previous hospitalization over the preceding six months [61] and by around three times for VRE colonization in a cross-sectional survey among 1215 residents of LTCF in Israel [126]. Hospital admission in the previous three months was also reported to be a risk factor for MDRO colonization [85].

There are no data on how long after hospital admission this risk increases. Thus, it remains unknown if hospital admission in the previous three months could entail greater risk for colonization than hospitalization in the last year. In the United Kingdom, a hospitalization duration of more than 10 days during the previous two years was independently associated with MRSA colonization; however, in this study, less than 10 days of hospitalization was not associated with MRSA colonization [77]. In a 351-bed community LTCF for older adults in Slovenia, multiple hospital admissions, defined as more than one instance of hospitalization in the three months before the investigation, increased the risk 
of MRSA colonization by around six times. In this study, a stratified analysis found that hospitalized residents with diabetes were 14 times more likely to be colonized compared to non-hospitalized diabetic residents [86].

In conclusion, previous hospitalization could be considered a risk factor for MDRO colonization among LTCF residents. However, to what extent this risk could be increased by days of hospitalization remains unknown.

\subsubsection{Previous Colonization by MDRO}

There is controversy about whether previous colonization with MDROs could be a risk factor for being colonized with an MDRO (Table 3). Two studies performed in Amsterdam [34] and Spain [85] showed that previous colonization with any MDRO was an independent risk factor for colonization with other MDROs (OR 4.7 (1.8-11.7) and (OR 10.89 (3.65-32.43), respectively). Another study performed by McKinnell et al. [97] showed that previous MDRO history was independently associated with colonization by MRSA [OR 3.6 (1.5-8.3)] and ESBL Enterobacterales [OR 4.1 (1.6-10.4)]. In contrast, Terveer et al. [109] did not find any association between previous colonization by MDROs and colonization by ESBL E. coli. At the individual pathogen level, previous colonization with MRSA has been reported as an independent risk factor for colonization with MRSA [42,43,57,83,84]. In the case of ESBL Enterobacterales, several studies reported an association between previous colonization with ESBL Enterobacterales and colonization with ESBL Enterobacterales [31,73,97]. however, one study performed by Latour et al. with 1447 residents from 29 LTCF did not find such a relationship [83]. The persistence of colonization was measured by Ludden et al. [18] in a study with 64 residents from one LTCF. Out of the 24 residents with ESBL E. coli, $75 \%$ remained positive for six months, and $42 \%$ remained positive for one year. Regarding VRE colonization, data from the SHIELD Orange Country Project performed by McKinell et al. [73] found that previous VRE history was associated with colonization by ESBL [OR 2.6 (1.3-5.3)] and CR Enterobacterales [OR 4.8 (1.3 17.9)]. Furthermore, Heinze et al. [66] reported that being previously colonized with MRSA or VRE was a significant predictor for becoming co-colonized by MRSA/VRE [hazard ratio (HR) 17.0 (5.3-54.6)] and [HR $6.3(2.2-18.2)]$.

Therefore, previous colonization with MRSA is clearly a risk factor for colonization with MRSA. In other MDROs, this relationship is not completely clear and could depend on other factors, in addition to previous colonization, that differ between studies. There is evidence that asymptomatic carriers may contribute to transmission and that implementing control measures is necessary to avoid an increase in reproductive numbers [146-148].

\section{Materials and Methods}

\subsection{Search Strategy}

A search was performed on the search engine PubMed and database Scopus for studies describing the prevalence of MDROs in LTCF or NH. The search terms used were related to microorganisms, such as "multidrug-resistant organism", "extendedspectrum B-lactamase Enterobacterales / Enterobacteriaceae", "extended-spectrum B-lactamase Escherichia coli", "extended-spectrum B-lactamase Klebsiella pneumoniae", "carbapenemresistant Enterobacterales/Enterobacteriaceae", "multidrug-resistant Pseudomonas aeruginosa", "multidrug-resistant Acinetobacter baumannii", "methicillin-resistant Staphylococcus aureus", "vancomycin-resistant Enterococcus", and "Clostridium/Clostridioides difficile" and those related to the site, such as "long term care facility" and "nursing home". The reference lists of the included studies were searched to identify further studies.

\subsection{Study Selection and Eligibility Criteria}

Inclusion criteria were defined as studies that analyzed and reported data on the prevalence and / or risk factors for the acquisition of MDROs in LTCF or NH. All types of studies were included, except for reviews. Restrictions on the year of publication were not established. Exclusion criteria included when studies reported data on non-MDROs 
and/or when the site was different from LTCF or NH healthcare settings (e.g., veterans' affairs centers, which provide acute inpatient and outpatient care) and/or when the studies analyzed infection by MDROs instead of colonization. Notably, the studies were selected and screened by two independent reviewers (ARV and CMG). Disagreements were resolved by consensus through discussions.

\subsection{Definitions}

The microorganisms selected for inclusion in this review are those commonly associated with MDR, such as Enterobacterales, especially E. coli and K. pneumoniae, P. aeruginosa, A. baumannii, S. aureus, and Enterococcus spp. We also included data on C. difficile colonization, because $C$. difficile is a healthcare-associated microorganism.

Focusing on antimicrobial resistance, ESBL was defined differently between the studies analyzed depending on the methodology and interpretation criteria used. To avoid confusion and the use of several terms, we grouped studies that reported both ESBL and resistance to third or fourth generation cephalosporins under the term "ESBL". For $P$. aeruginosa or A. baumannii, MDR was considered as resistance to carbapenems and/or resistance to three or more classes of antibiotics comprising cephalosporins, carbapenems, quinolones, and aminoglycosides.

For the healthcare setting, LTCF and NH are similar terms used to describe sites that provide living accommodations for people who require the on-site delivery of supervised care $24 \mathrm{~h}$ per day, 7 days per week. Importantly, not all residents of LTCF are older adults [149].

\section{Conclusions}

The prevalence of MDROs in LTCF varies across the world, showing great differences across continents. Asia has the highest prevalence of ESBL Enterobacterales, CR Enterobacterales, and MRSA, while North America has the highest prevalence of MDR P. aeruginosa and MDR A. baumannii. North America also has the highest prevalence of $C$. difficile, but this prevalence has changed over the years. In general, since 2015, the prevalence of $C R$ Enterobacterales, MDR A. baumannii, MRSA, VRE, and C. difficile has experienced a decrease. In contrast, the prevalence of ESBL Enterobacterales and MDR P. aeruginosa has increased in recent years.

Living in NH and other LTCF is itself a risk factor for being colonized by MDROs. This is a non-modifiable factor and must be taken into account at hospital admission. Most risk factors for colonization with MDROs in LTCF cannot be modified. Risk factors related to age, sex, dependence, or underlying diseases should lead healthcare professionals to intensify aseptic and antiseptic measures to optimize healthcare management. However, there are modifiable factors that we can work on by designing optimal strategies to reduce MDRO propagation and improve the quality of life among the residents in LTCF. The optimal management of medical devices and healthcare for chronic wounds have a significant impact on reducing MDRO colonization. However, the principal modifiable factor is to ensure correct antibiotic use, for which the implementation of ASP would be a useful tool, following the recommendations of the CDC and other scientific and governmental organizations.

Further research is required on the epidemiology of MDRO colonization in LTCF to analyze the risk factors. Standard criteria are necessary to determine the level of dementia or dependence and thereby allow us to grade the residents as high or low risk for colonization by MDROs based on a standard score, including main aspects, such as dependence, dementia, devices, and diseases.

Author Contributions: J.M.C.; methodology, Á.R.-V. and C.M.-G.; formal analysis, Á.R.-V. and C.M.G. writing - original draft preparation, Á.R.-V. and C.M.-G.; writing—review and editing, A.B.G.-G., J.C.C.-R., G.P., M.E.P.-I., J.A.L. and J.M.C.; supervision, J.M.C.; project administration, J.M.C.; funding acquisition, J.M.C. All authors have read and agreed to the published version of the manuscript." 
Please turn to the CRediT taxonomy for the term explanation. Authorship must be limited to those who have contributed substantially to the work reported.

Funding: The study was funded by the Instituto de Salud Carlos III, the Spanish Ministry of Economy, Industry, and Competitiveness (grant number: PI17-02195) and was partially funded by the European Development Regional Fund "A way to achieve Europe". A.R.V. and A.B.G.G. are supported by the Subprograma Río Hortega, Instituto de Salud Carlos III, Subdirección General de Redes y Centros de Investigación Cooperativa, Ministerio de Ciencia, Innovación y Universidades, Spain. A.R.V. grant number: CM18/00122. A.B.G.G. grant number: CM19/00029. C.M.G. and J.C.C.R. are supported by the Instituto de Salud Carlos III (grant number: PI17-02195) and co-financed by European Development Regional Fund 'A way to achieve Europe' ERDF, Spanish Network for the Research in Infectious Diseases (REIPI RD16/0016/0009).G.P. is supported by the Instituto de Salud Carlos III, Subdirección General de Redes y Centros de Investigación Cooperativa, Ministerio de Economía, Industria y Competitividad, Spanish Network for Research in Infectious Diseases (REIPI RD16/0016/0001)- co-financed by European Development Regional Fund "A way to achieve Europe", Operative program Intelligent Growth 2014-2020. M.E.P.I. is a postdoctoral researcher belonging to the program "Nicolás Monardes" (C1-0038-2019), Servicio Andaluz de Salud, Junta de Andalucía, Spain. J.M.C. received funding for research from Plan Nacional de I+D+i 2013-2016 and Instituto de Salud Carlos III, Subdireccion General de Redes y Centros de InvestigacionCooperativa, Ministry of Economy, Industry and Competitiveness, Spanish Network for Research in Infectious Diseases (REIPI RD16/0016/0001, RD16/0016/0009), co-financed by the European Development Regional Fund "A way to achieve Europe".

Institutional Review Board Statement: Not applicable.

Informed Consent Statement: Not applicable.

Conflicts of Interest: J.M.C. received travel grants and honoraria as a speaker from Novartis, Astellas Pharma, Pfizer, MSD, Janssen Pharmaceuticals, and AstraZeneca, outside the submitted work. All other authors declare no conflict of interest.

\section{References}

1. Stepan, D.; Ušaj, L.; Šter, M.P.; Galun, M.S.; Smole, H.; Beović, B. Antimicrobial prescribing in long-term care facilities: A nationwide point-prevalence study, Slovenia, 2016. Eurosurveillance 2018, 23, 1800100. [CrossRef] [PubMed]

2. O'Neill, D.; Briggs, R.; Holmerová, I.; Samuelsson, O.; Gordon, A.L.; Martin, F.C.; The Special Interest Group in Long Term Care of the European Geriatric Medicine Society. COVID-19 highlights the need for universal adoption of standards of medical care for physicians in nursing homes in Europe. Eur. Geriatr. Med. 2020, 11, 645-650. [CrossRef]

3. Infectious Diseases Society of America; Spellberg, B.; Blaser, M.; Guidos, R.J.; Boucher, H.W.; Bradley, J.S.; Eisenstein, B.I.; Gerding, D.; Lynfield, R.; Reller, L.B.; et al. Combating Antimicrobial Resistance: Policy Recommendations to Save Lives. Clin. Infect. Dis. 2011, 52, S397-S428. [CrossRef]

4. van Duin, D.; Paterson, D.L. Multidrug-Resistant Bacteria in the Community. Infect. Dis. Clin. N. Am. 2016, 30, 377-390. [CrossRef]

5. Vehreschild, M.J.G.T.; Haverkamp, M.; Biehl, L.M.; Lemmen, S.; Fätkenheuer, G. Vancomycin-resistant enterococci (VRE): A reason to isolate? Infection 2019, 47, 7-11. [CrossRef] [PubMed]

6. Horcajada, J.P.; Montero, M.; Oliver, A.; Sorlí, L.; Luque, S.; Gómez-Zorrilla, S.; Benito, N.; Grau, S. Epidemiology and Treatment of Multidrug-Resistant and Extensively Drug-Resistant Pseudomonas aeruginosa Infections. Clin. Microbiol. Rev. 2019, 32, 00031-19. [CrossRef] [PubMed]

7. Perez, F.; Hujer, A.M.; Hujer, K.M.; Decker, B.K.; Rather, P.N.; Bonomo, R.A. Global Challenge of Multidrug-Resistant Acinetobacter baumannii. Antimicrob. Agents Chemother. 2007, 51, 3471-3484. [CrossRef]

8. Barbut, F.; Jones, G.; Eckert, C. Epidemiology and control of Clostridium difficile infections in healthcare settings. Curr. Opin. Infect. Dis. 2011, 24, 370-376. [CrossRef] [PubMed]

9. Rodriguez, C.; Korsak, N.; Taminiau, B.; Avesani, V.; Van Broeck, J.; Delmée, M.; Daube, G. Clostridium difficile infection in elderly nursing home residents. Anaerobe 2014, 30, 184-187. [CrossRef] [PubMed]

10. Bell, B.G.; Schellevis, F.; Stobberingh, E.; Goossens, H.; Pringle, M. A systematic review and meta-analysis of the effects of antibiotic consumption on antibiotic resistance. BMC Infect. Dis. 2014, 14, 13. [CrossRef]

11. Molina, J.; Peñalva, G.; Gil-Navarro, M.V.; Praena, J.; Lepe, J.A.; Pérez-Moreno, M.A.; Ferrándiz, C.; Aldabó, T.; Aguilar, M.; Olbrich, P.; et al. Long-Term Impact of an Educational Antimicrobial Stewardship Program on Hospital-Acquired Candidemia and Multidrug-Resistant Bloodstream Infections: A Quasi-Experimental Study of Interrupted Time-Series Analysis. Clin. Infect. Dis. 2017, 65, 1992-1999. [CrossRef] [PubMed]

12. Batina, N.G.; Crnich, C.J.; Döpfer, D. Acquisition and persistence of strain-specific methicillin-resistant Staphylococcus aureus and their determinants in community nursing homes. BMC Infect. Dis. 2017, 17, 752. [CrossRef] 
13. Kohler, P.; Fulchini, R.; Albrich, W.C.; Egli, A.; Balmelli, C.; Harbarth, S.; Héquet, D.; Kahlert, C.R.; Kuster, S.P.; Petignat, C.; et al. Antibiotic resistance in Swiss nursing homes: Analysis of National Surveillance Data over an 11-year period between 2007 and 2017. Antimicrob. Resist. Infect. Control. 2018, 7, 88. [CrossRef] [PubMed]

14. Mylotte, J.M.; Goodnough, S.; Tayara, A. Antibiotic-resistant organisms among long-term care facility residents on admission to an inpatient geriatrics unit: Retrospective and prospective surveillance. Am. J. Infect. Control. 2001, 29, 139-144. [CrossRef]

15. Drayß, M.; Claus, H.; Hubert, K.; Thiel, K.; Berger, A.; Sing, A.; Van Der Linden, M.; Vogel, U.; Lâm, T.-T. Asymptomatic carriage of Neisseria meningitidis, Haemophilus influenzae, Streptococcus pneumoniae, Group A Streptococcus and Staphylococcus aureus among adults aged 65 years and older. PLoS ONE 2019, 14, e0212052. [CrossRef] [PubMed]

16. Verhoef, L.; Roukens, M.; De Greeff, S.; Meessen, N.; Natsch, S.; Stobberingh, E. Carriage of antimicrobial-resistant commensal bacteria in Dutch long-term-care facilities. J. Antimicrob. Chemother. 2016, 71, 2586-2592. [CrossRef]

17. Brugnaro, P.; Fedeli, U.; Pellizzer, G.; Buonfrate, D.; Rassu, M.; Boldrin, C.; Parisi, S.G.; Grossato, A.; Palù, G.; Spolaore, P. Clustering and Risk Factors of Methicillin-Resistant Staphylococcus aureus Carriage in Two Italian Long-Term Care Facilities. Infection 2008, 37, 216-221. [CrossRef] [PubMed]

18. Ludden, C.; Cormican, M.; Vellinga, A.; Johnson, J.R.; Austin, B.; Morris, D. Colonisation with ESBL-producing and carbapenemase-producing Enterobacteriaceae, vancomycin-resistant enterococci, and meticillin-resistant Staphylococcus aureus in a long-term care facility over one year. BMC Infect. Dis. 2015, 15, 168. [CrossRef]

19. Giufrè, M.; Ricchizzi, E.; Accogli, M.; Barbanti, F.; Monaco, M.; De Araujo, F.P.; Farina, C.; Fazii, P.; Mattei, R.; Sarti, M.; et al. Colonization by multidrug-resistant organisms in long-term care facilities in Italy: A point-prevalence study. Clin. Microbiol. Infect. 2017, 23, 961-967. [CrossRef]

20. Nucleo, E.; Caltagirone, M.; Marchetti, V.M.; D’Angelo, R.; Fogato, E.; Confalonieri, M.; Reboli, C.; March, A.; Sleghel, F.; Soelva, G.; et al. Colonization of long-term care facility residents in three Italian Provinces by multidrug-resistant bacteria. Antimicrob. Resist. Infect. Control. 2018, 7, 33. [CrossRef]

21. March, A.; Aschbacher, R.; Sleghel, F.; Soelva, G.; Kaczor, M.; Migliavacca, R.; Piazza, A.; Mattioni Marchetti, V.; Pagani, L.; Scalzo, K.; et al. Colonization of residents and staff of an Italian long-term care facility and an adjacent acute care hospital geriatric unit by multidrug-resistant bacteria. New Microbiol. 2017, 40, 258-263. [PubMed]

22. March, A.; Aschbacher, R.; Dhanji, H.; Livermore, D.M.; Böttcher, A.; Sleghel, F.; Maggi, S.; Noale, M.; Larcher, C.; Woodford, N. Colonization of residents and staff of a long-term-care facility and adjacent acute-care hospital geriatric unit by multiresistant bacteria. Clin. Microbiol. Infect. 2010, 16, 934-944. [CrossRef] [PubMed]

23. Trick, W.E.; Weinstein, R.A.; DeMarais, P.L.; Kuehnert, M.J.; Tomaska, W.; Nathan, C.; Rice, T.W.; McAllister, S.K.; Carson, L.A.; Jarvis, W.R. Colonization of Skilled-Care Facility Residents with Antimicrobial-Resistant Pathogens. J. Am. Geriatr. Soc. 2001, 49, 270-276. [CrossRef]

24. Roghmann, M.-C.; Lydecker, A.D.; Hittle, L.; DeBoy, R.T.; Nowak, R.G.; Johnson, J.K.; Mongodin, E.F. Comparison of the Microbiota of Older Adults Living in Nursing Homes and the Community. mSphere 2017, 2, e00210-17. [CrossRef]

25. Hogardt, M.; Proba, P.; Mischler, D.; Cuny, C.; Kempf, V.A.; Heudorf, U. Current prevalence of multidrug-resistant organisms in long-term care facilities in the Rhine-Main district, Germany, 2013. Eurosurveillance 2015, 20, 21171. [CrossRef] [PubMed]

26. Tsao, F.-Y.; Kou, H.-W.; Huang, Y.-C. Dissemination of methicillin-resistant Staphylococcus aureus sequence type 45 among nursing home residents and staff in Taiwan. Clin. Microbiol. Infect. 2015, 21, 451-458. [CrossRef] [PubMed]

27. Hudson, L.O.; Reynolds, C.; Spratt, B.G.; Enright, M.C.; Quan, V.; Kim, D.; Hannah, P.; Mikhail, L.; Alexander, R.; Moore, D.F.; et al. Diversity of Methicillin-Resistant Staphylococcus aureus Strains Isolated from Residents of 26 Nursing Homes in Orange County, California. J. Clin. Microbiol. 2013, 51, 3788-3795. [CrossRef]

28. Cheng, V.C.C.; Chen, J.H.K.; Ng, W.C.; Wong, J.Y.H.; Chow, D.M.K.; Law, T.C.; So, S.Y.C.; Wong, S.C.Y.; Chan, T.C.; Chan, F.H.W.; et al. Emergence of Carbapenem-Resistant Acinetobacter baumannii in Nursing Homes With High Background Rates of MRSA Colonization. Infect. Control Hosp. Epidemiol. 2016, 37, 983-986. [CrossRef]

29. Mody, L.; Kauffman, C.A.; Donabedian, S.; Zervos, M.; Bradley, S.F. Epidemiology of Staphylococcus aureus Colonization in Nursing Home Residents. Clin. Infect. Dis. 2008, 46, 1368-1373. [CrossRef]

30. Denis, O.; Jans, B.; Deplano, A.; Nonhoff, C.; De Ryck, R.; Suetens, C.; Struelens, M.J. Epidemiology of methicillin-resistant Staphylococcus aureus (MRSA) among residents of nursing homes in Belgium. J. Antimicrob. Chemother. 2009, 64, 1299-1306. [CrossRef]

31. Jans, B.; Schoevaerdts, D.; Huang, T.-D.; Berhin, C.; Latour, K.; Bogaerts, P.; Nonhoff, C.; Denis, O.; Catry, B.; Glupczynski, Y. Epidemiology of Multidrug-Resistant Microorganisms among Nursing Home Residents in Belgium. PLoS ONE 2013, 8, e64908. [CrossRef]

32. Kotilainen, P.; Routamaa, M.; Peltonen, R.; Evesti, P.; Eerola, E.; Salmenlinna, S.; Vuopio-Varkila, J.; Rossi, T. Eradication of methicillin-resistant Staphylococcus aureus from a health center ward and associated nursing home. Arch. Intern. Med. 2001, 161, 859-863. [CrossRef]

33. Min, L.; Galecki, A.; Mody, L. Functional Disability and Nursing Resource Use Are Predictive of Antimicrobial Resistance in Nursing Homes. J. Am. Geriatr. Soc. 2015, 63, 659-666. [CrossRef] [PubMed]

34. Van Dulm, E.; Tholen, A.T.R.; Pettersson, A.; Van Rooijen, M.S.; Willemsen, I.; Molenaar, P.; Damen, M.; Gruteke, P.; Oostvogel, P.; Kuijper, E.J.; et al. High prevalence of multidrug resistant Enterobacteriaceae among residents of long term care facilities in Amsterdam, the Netherlands. PLoS ONE 2019, 14, e0222200. [CrossRef] [PubMed] 
35. Verrall, A.; Merchant, R.; Dillon, J.; Ying, D.; Fisher, D. Impact of nursing home residence on hospital epidemiology of meticillinresistant Staphylococcus aureus: A perspective from Asia. J. Hosp. Infect. 2013, 83, 250-252. [CrossRef]

36. Stone, N.D.; Lewis, D.R.; Lowery, H.K.; Darrow, L.A.; Kroll, C.M.; Gaynes, R.P.; Jernigan, J.A.; McGowan, J.E.; Tenover, F.C.; Richards, C.L. Importance of Bacterial Burden Among Methicillin-Resistant Staphylococcus aureus Carriers in a Long-Term Care Facility. Infect. Control Hosp. Epidemiol. 2008, 29, 143-148. [CrossRef]

37. Hübner, N.; Dittmann, K.; Begunk, R.; Kramer, A. Infection control measures and prevalence of multidrug-resistant organisms in non-hospital care settings in northeastern Germany: Results from a one-day point prevalence study. J. Hosp. Infect. 2017, 97, 234-240. [CrossRef] [PubMed]

38. Mitchell, S.L.; Shaffer, M.L.; Loeb, M.B.; Givens, J.L.; Habtemariam, D.; Kiely, D.K.; D'Agata, E. Infection Management and Multidrug-Resistant Organisms in Nursing Home Residents With Advanced Dementia. JAMA Intern. Med. 2014, 174, 1660-1667. [CrossRef]

39. Ruscher, C.; Pfeifer, Y.; Layer, F.; Schaumann, R.; Levin, K.; Mielke, M. Inguinal skin colonization with multidrug-resistant bacteria among residents of elderly care facilities: Frequency, persistence, molecular analysis and clinical impact. Int. J. Med. Microbiol. 2014, 304, 1123-1134. [CrossRef]

40. Greenland, K.; Rijnders, M.I.; Mulders, M.; Haenen, A.; Spalburg, E.; Van De Kassteele, J.; De Neeling, A.; Stobberingh, E. Low Prevalence of Methicillin-Resistant Staphylococcus Aureus in Dutch Nursing Homes. J. Am. Geriatr. Soc. 2011, 59, 768-769. [CrossRef] [PubMed]

41. Gibson, K.E.; McNamara, S.E.; Cassone, M.; Perri, M.B.; Zervos, M.; Mody, L.; on behalf of the Targeted Infection Prevention (TIP) Study Team, Ann Arbor, Michigan. Methicillin-Resistant Staphylococcus aureus:Site of Acquisition and Strain Variation in High-Risk Nursing Home Residents with Indwelling Devices. Infect. Control Hosp. Epidemiol. 2014, 35, 1458-1465. [CrossRef]

42. Reynolds, C.; Quan, V.; Kim, D.; Peterson, E.; Dunn, J.; Whealon, M.; Terpstra, L.; Meyers, H.; Cheung, M.; Lee, B.; et al. Methicillin-Resistant Staphylococcus aureus (MRSA) Carriage in 10 Nursing Homes in Orange County, California. Infect. Control Hosp. Epidemiol. 2011, 32, 91-93. [CrossRef]

43. Murphy, S.; Denman, S.; Bennett, R.G.; Greenough, W.B.; Lindsay, J.; Zelesnick, L.B. Methicillin-ResistantStaphylococcus aureusColonization in a Long-Term-Care Facility. J. Am. Geriatr. Soc. 1992, 40, 213-217. [CrossRef]

44. Storch, G.A.; Radcliff, J.L.; Meyer, P.L.; Hinrichs, J.H. Methicillin-Resistant Staphylococcus aureus in a Nursing Home. Infect. Control. 1987, 8, 24-29. [CrossRef]

45. Muder, R.R.; Brennen, C.; Wagener, M.M.; Vickers, R.M.; Rihs, J.D.; Hancock, G.A.; Yee, Y.C.; Miller, J.M.; Yu, V.L. MethicillinResistant Staphylococcal Colonization and Infection in a Long-Term Care Facility. Ann. Intern. Med. 1991, 114, 107-112. [CrossRef]

46. Eveillard, M.; Charru, P.; Rufat, P.; Hippeaux, M.-C.; Lancien, E.; Benselama, F.; Branger, C. Methicillin-resistant Staphylococcus aureus carriage in a long-term care facility: Hypothesis about selection and transmission. Age Ageing 2008, 37, 294-299. [CrossRef]

47. Cox, R.; Bowie, P. Methicillin-resistant Staphylococcus aureus colonization in nursing home residents: A prevalence study in Northamptonshire. J. Hosp. Infect. 1999, 43, 115-122. [CrossRef] [PubMed]

48. Suetens, C.; Niclaes, L.; Jans, B.; Verhaegen, J.; Schuermans, A.; Van Eldere, J.; Buntinx, F. Methicillin-Resistant Staphylococcus aureus Colonization Is Associated with Higher Mortality in Nursing Home Residents with Impaired Cognitive Status. J. Am. Geriatr. Soc. 2006, 54, 1854-1860. [CrossRef] [PubMed]

49. Nillius, D.; Von Müller, L.; Wagenpfeil, S.; Klein, R.; Herrmann, M. Methicillin-Resistant Staphylococcus aureus in Saarland, Germany: The Long-Term Care Facility Study. PLoS ONE 2016, 11, e0153030. [CrossRef]

50. Namnyak, S.; Adhami, Z.; Wilmore, M.; Keynes, H.; Hampton, K.; Mercieca, E.; Roker, K. Methicillin-resistant Staphylococcus aureus: A questionnaire and microbiological survey of nursing and residential homes in Barking, Havering and Brentwood. $J$. Infect. 1998, 36, 67-72. [CrossRef]

51. Bradley, S.F.; Terpenning, M.S.; Ramsey, M.A.; Zarins, L.T.; Jorgensen, K.A.; Sottile, W.S.; Schaberg, D.R.; Kauffman, C.A. Methicillin-resistant Staphylococcus aureus: Colonization and Infection in a Long-term Care Facility. Ann. Intern. Med. 1991, 115, 417-422. [CrossRef] [PubMed]

52. Monaco, M.; Bombana, E.; Trezzi, L.; Regattin, L.; Brusaferro, S.; Pantosti, A.; Goglio, A. Meticillin-resistant Staphylococcus aureus colonising residents and staff members in a nursing home in Northern Italy. J. Hosp. Infect. 2009, 73, 182-184. [CrossRef] [PubMed]

53. Horner, C.; Parnell, P.; Hall, D.; Kearns, A.; Heritage, J.; Wilcox, M. Meticillin-resistant Staphylococcus aureus in elderly residents of care homes: Colonization rates and molecular epidemiology. J. Hosp. Infect. 2013, 83, 212-218. [CrossRef]

54. Ho, P.-L.; Lai, E.L.; Chow, K.-H.; Chow, L.S.; Yuen, K.-Y.; Yung, R.W. Molecular epidemiology of methicillin-resistant Staphylococcus aureus in residential care homes for the elderly in Hong Kong. Diagn. Microbiol. Infect. Dis. 2008, 61, 135-142. [CrossRef] [PubMed]

55. Peters, C.; Dulon, M.; Kleinmüller, O.; Nienhaus, A.; Schablon, A. MRSA Prevalence and Risk Factors among Health Personnel and Residents in Nursing Homes in Hamburg, Germany-A Cross-Sectional Study. PLoS ONE 2017, 12, e0169425. [CrossRef]

56. Friedewald, M.; de Wit, D. MRSA screening of nursing home, residents admitted to hospital on the NSW Central Coast. Aust. Infect. Control. 2001, 6, 119-121. [CrossRef] 
57. Gruber, I.; Heudorf, U.; Werner, G.; Pfeifer, Y.; Imirzalioglu, C.; Ackermann, H.; Brandt, C.; Besier, S.; Wichelhaus, T.A. Multidrugresistant bacteria in geriatric clinics, nursing homes, and ambulant care-Prevalence and risk factors. Int. J. Med. Microbiol. 2013, 303, 405-409. [CrossRef] [PubMed]

58. O'Fallon, E.; Schreiber, R.; Kandel, R.; D'Agata, E.M.C. Multidrug-Resistant Gram-Negative Bacteria at a Long-Term Care Facility: Assessment of Residents, Healthcare Workers, and Inanimate Surfaces. Infect. Control Hosp. Epidemiol. 2009, 30, 1172-1179. [CrossRef] [PubMed]

59. Pop-Vicas, A.; Mitchell, S.L.; Kandel, R.; Schreiber, R.; D'Agata, E.M.C. Multidrug-Resistant Gram-Negative Bacteria in a Long-Term Care Facility: Prevalence and Risk Factors. J. Am. Geriatr. Soc. 2008, 56, 1276-1280. [CrossRef]

60. Chen, H.; Au, K.M.; Hsu, K.E.; Lai, C.K.; Myint, J.; Mak, Y.F.; Lee, S.Y.; Wong, T.Y.; Tsang, N.C. Multidrug-resistant organism carriage among residents from residential care homes for the elderly in Hong Kong: A prevalence survey with stratified cluster sampling. Hong Kong Med. J. 2018, 24, 350-360. [CrossRef]

61. Da Silveira, M.; Cunha, M.D.L.R.D.S.D.; De Souza, C.S.M.; Correa, A.A.F.; Fortaleza, C.M.C.B. Nasal colonization with methicillinresistant Staphylococcus aureus among elderly living in nursing homes in Brazil: Risk factors and molecular epidemiology. Ann. Clin. Microbiol. Antimicrob. 2018, 17, 1-5. [CrossRef] [PubMed]

62. Kwetkat, A.; Pfister, W.; Pansow, D.; Pletz, M.W.; Sieber, C.C.; Hoyer, H. Naso- and oropharyngeal bacterial carriage in nursing home residents: Impact of multimorbidity and functional impairment. PLoS ONE 2018, 13, e0190716. [CrossRef] [PubMed]

63. Manzur, A.; Domínguez, M.A.; de Gopegui, E.R.; Mariscal, D.; Gavalda, L.; Segura, F.; Perez, J.; Pujol, M. Natural history of meticillin-resistant Staphylococcus aureus colonisation among residents in community long term care facilities in Spain. J. Hosp. Infect. 2010, 76, 215-219. [CrossRef] [PubMed]

64. Wang, J.; Foxman, B.; Mody, L.; Snitkin, E.S. Network of microbial and antibiotic interactions drive colonization and infection with multidrug-resistant organisms. Proc. Natl. Acad. Sci. USA 2017, 114, 10467-10472. [CrossRef] [PubMed]

65. Fisch, J.; Lansing, B.; Wang, L.; Symons, K.; Cherian, K.; McNamara, S.; Mody, L. New Acquisition of Antibiotic-Resistant Organisms in Skilled Nursing Facilities. J. Clin. Microbiol. 2012, 50, 1698-1703. [CrossRef] [PubMed]

66. Heinze, K.; Kabeto, M.; Martin, E.T.; Cassone, M.; Hicks, L.; Mody, L. Predictors of methicillin-resistant Staphylococcus aureus and vancomycin-resistant enterococci co-colonization among nursing facility patients. Am. J. Infect. Control. 2019, 47, 415-420 [CrossRef]

67. Lee, C.-M.; Lai, C.-C.; Chiang, H.-T.; Lu, M.-C.; Wang, L.-F.; Tsai, T.-L.; Kang, M.-Y.; Jan, Y.-N.; Lo, Y.-T.; Ko, W.-C.; et al. Presence of multidrug-resistant organisms in the residents and environments of long-term care facilities in Taiwan. J. Microbiol. Immunol. Infect. 2017, 50, 133-144. [CrossRef]

68. Budimir, A.; Pal, M.P.; Bošnjak, Z.; Mareković, I.; Vuković, D.; Križan, I.R.; Milas, J.; Plečko, V.; Kalenić, S. Prevalence and molecular characteristics of methicillin-resistant Staphylococcus aureus strains isolated in a multicenter study of nursing home residents in Croatia. Am. J. Infect. Control. 2014, 42, 1197-1202. [CrossRef]

69. Zhang, J.; Gu, F.-F.; Zhao, S.-Y.; Xiao, S.-Z.; Wang, Y.-C.; Guo, X.-K.; Ni, Y.-X.; Han, L.-Z. Prevalence and Molecular Epidemiology of Staphylococcus aureus among Residents of Seven Nursing Homes in Shanghai. PLoS ONE 2015, 10, e0137593. [CrossRef]

70. Moschou, A.; Maraki, S.; Giormezis, N.; Moraitaki, H.; Stafylaki, D.; Militsopoulou, M.; Spiliopoulou, I.; Papadakis, J.; Samonis, G.; Kofteridis, D. Prevalence and molecular epidemiology of Staphylococcus aureus nasal colonization in four nursing home residents in Crete, Greece. J. Infect. Chemother. 2020, 26, 199-204. [CrossRef]

71. Cretnik, T.Z.; Vovko, P.; Retelj, M.; Juteršek, B.; Harlander, T.; Kolman, J.; Gubina, M. Prevalence and Nosocomial Spread of Methicillin-ResistantStaphylococcus aureusin a Long-Term-Care Facility in Slovenia. Infect. Control Hosp. Epidemiol. 2005, 26, 184-190. [CrossRef]

72. Barrufet, M.P.; Vendrell, E.; Force, L.; Sauca, G.; Rodríguez, S.; Martínez, E.; Palomera, E.; Serra-Prat, M.; Capdevila, J.A.; Cornudella, J.; et al. Prevalence and risk factors for meticillin-resistant Staphylococcus aureus in an acute care hospital and long-term care facilities located in the same geographic area. Rev. Esp. Quimioter. 2014, 27, 190-195. [PubMed]

73. McKinnell, J.A.; Singh, R.D.; Miller, L.G.; Kleinman, K.; Gussin, G.; He, J.; Saavedra, R.; Dutciuc, T.D.; Estevez, M.; Chang, J.; et al. The SHIELD Orange County Project: Multidrug-resistant Organism Prevalence in 21 Nursing Homes and Long-term Acute Care Facilities in Southern California. Clin. Infect. Dis. 2019, 69, 1566-1573. [CrossRef]

74. Mody, L.; Gibson, K.E.; Horcher, A.; Prenovost, K.; McNamara, S.E.; Foxman, B.; Kaye, K.S.; Bradley, S. Prevalence of and Risk Factors for Multidrug-Resistant Acinetobacter baumannii Colonization Among High-Risk Nursing Home Residents. Infect. Control Hosp. Epidemiol. 2015, 36, 1155-1162. [CrossRef] [PubMed]

75. Hoogendoorn, M.; Smalbrugge, M.; Stobberingh, E.E.; van Rossum, S.V.; Vlaminckx, B.J.; Thijsen, S.F. Prevalence of Antibiotic Resistance of the Commensal Flora in Dutch Nursing Homes. J. Am. Med. Dir. Assoc. 2013, 14, 336-339. [CrossRef] [PubMed]

76. Andersson, H.; Lindholm, C.; Iversen, A.; Giske, C.G.; Örtqvist, Å.; Kalin, M.; Fossum, B. Prevalence of antibiotic-resistant bacteria in residents of nursing homes in a Swedish municipality: Healthcare staff knowledge of and adherence to principles of basic infection prevention. Scand. J. Infect. Dis. 2012, 44, 641-649. [CrossRef] [PubMed]

77. Barr, B.; Wilcox, M.H.; Brady, A.; Parnell, P.; Darby, B.; Tompkins, D. Prevalence of Methicillin-ResistantStaphylococcus aureusColonization Among Older Residents of Care Homes in the United Kingdom. Infect. Control Hosp. Epidemiol. 2007, 28, 853-859. [CrossRef] 
78. Furuno, J.P.; Hebden, J.N.; Standiford, H.C.; Perencevich, E.N.; Miller, R.R.; Moore, A.C.; Strauss, S.M.; Harris, A.D. Prevalence of methicillin-resistant Staphylococcus aureus and Acinetobacter baumannii in a long-term acute care facility. Am. J. Infect. Control. 2008, 36, 468-471. [CrossRef]

79. Manzur, A.; Gavalda, L.; de Gopegui, E.R.; Mariscal, D.; Domínguez, M.A.; Perez, J.; Segura, F.; Pujol, M. Prevalence of methicillinresistant Staphylococcus aureus and factors associated with colonization among residents in community long-term-care facilities in Spain. Clin. Microbiol. Infect. 2008, 14, 867-872. [CrossRef]

80. Baldwin, N.S.; Gilpin, D.; Hughes, C.M.; Kearney, M.P.; Gardiner, D.A.; Cardwell, C.; Tunney, M.M. Prevalence of MethicillinResistant Staphylococcus aureus Colonization in Residents and Staff in Nursing Homes in Northern Ireland. J. Am. Geriatr. Soc. 2009, 57, 620-626. [CrossRef]

81. Flint, J.A.; Ryan, P.; Gordon, D.L. Prevalence of MRSA in South Australian nursing homes. Med. J. Aust. 1998, 169, 559-560. [CrossRef] [PubMed]

82. Lim, C.J.; Cheng, A.; Kennon, J.; Spelman, D.; Hale, D.; Melican, G.; Sidjabat, H.E.; Paterson, D.L.; Kong, D.; Peleg, A.Y. Prevalence of multidrug-resistant organisms and risk factors for carriage in long-term care facilities: A nested case-control study. J. Antimicrob. Chemother. 2014, 69, 1972-1980. [CrossRef]

83. Latour, K.; Huang, T.-D.; Jans, B.; Berhin, C.; Bogaerts, P.; Noel, A.; Nonhoff, C.; Dodémont, M.; Denis, O.; Ieven, M.; et al. Prevalence of multidrug-resistant organisms in nursing homes in Belgium in 2015. PLoS ONE 2019, 14, e0214327. [CrossRef] [PubMed]

84. Mossong, J.; Gelhausen, E.; Decruyenaere, F.; Devaux, A.; Perrin, M.; Even, J.; Heisbourg, E. Prevalence, risk factors and molecular epidemiology of methicillin-resistantStaphylococcus aureus(MRSA) colonization in residents of long-term care facilities in Luxembourg, 2010. Epidemiol. Infect. 2012, 141, 1199-1206. [CrossRef] [PubMed]

85. Del Rosario-Quintana, C.; Tosco-Núñez, T.; Lorenzo, L.; Martín-Sánchez, A.M.; Molina-Cabrillana, J. Prevalencia y factores asociados a la colonización de microorganismos multirresistentes en centros de larga estancia de Gran Canaria. Revista Española de Geriatría y Gerontología 2015, 50, 232-236. [CrossRef]

86. Vovko, P.; Retelj, M.; Cretnik, T.Z.; Jutersek, B.; Harlander, T.; Kolman, J.; Gubina, M. Risk Factors for Colonization With Methicillin-ResistantStaphylococcus aureusin a Long-Term-Care Facility in Slovenia. Infect. Control Hosp. Epidemiol. 2005, 26, 191-195. [CrossRef] [PubMed]

87. Gu, F.-F.; Zhang, J.; Zhao, S.-Y.; Yang, Z.-R.; Zhang, Y.-L.; Xiao, S.-Z.; Wang, S.; Guo, X.-K.; Qu, J.-M.; Ni, Y.-X.; et al. Risk factors for methicillin-resistant Staphylococcus aureus carriage among residents in 7 nursing homes in Shanghai, China. Am. J. Infect. Control. 2016, 44, 805-808. [CrossRef]

88. Becker, J.; Diel, R. Screening for Methicillin-resistant Staphylococcus aureus in a residence home for elderly in Germany. J. Occup. Med. Toxicol. 2017, 12, 3. [CrossRef]

89. El Emam, K.; Arbuckle, L.; Essex, A.; Samet, S.; Eze, B.; Middleton, G.; Buckeridge, D.; Jonker, E.; Moher, E.; Earle, C. Secure Surveillance of Antimicrobial Resistant Organism Colonization or Infection in Ontario Long Term Care Homes. PLoS ONE 2014, 9, e93285. [CrossRef]

90. Cederna, J.E.; Terpenning, M.S.; Ensberg, M.; Bradley, S.F.; Kauffman, C.A. StaphylococcusaureusNasal Colonization in a Nursing Home: Eradication With Mupirocin. Infect. Control Hosp. Epidemiol. 1990, 11, 13-16. [CrossRef]

91. Lasseter, G.; Charlett, A.; Lewis, D.L.; Donald, I.P.; Howelljones, R.; McNulty, C.A.M. Staphylococcus aureus carriage in care homes: Identification of risk factors, including the role of dementia. Epidemiol. Infect. 2010, 138, 686-696. [CrossRef]

92. Galán-Sánchez, F.; Pérez-Eslava, M.; Machuca, J.; Trujillo-Soto, T.; Arca-Suárez, J.; Rodríguez-Iglesias, M. Staphylococcus aureus carriage in older populations in community residential care homes: Prevalence and molecular characterization of MRSA isolates. Enfermedades Infecciosas y Microbiología Clínica 2019, 37, 172-175. [CrossRef]

93. Kerttula, A.-M.; Lyytikäinen, O.; Virolainen, A.; Finne-Soveri, H.; Agthe, N.; Vuopio-Varkila, J. Staphylococcus aureus colonization among nursing home residents in a large Finnish nursing home. Scand. J. Infect. Dis. 2007, 39, 996-1001. [CrossRef] [PubMed]

94. Lee, Y.-L.; Cesario, T.; Gupta, G.; Flionis, L.; Tran, C.; Decker, M.; Thrupp, L. Surveillance of colonization and infection with Staphylococcus aureus susceptible or resistant to methicillin in a community skilled-nursing facility. Am. J. Infect. Control. 1997, 25, 312-321. [CrossRef]

95. Chan, T.C.; Cheng, V.C.C.; Hung, I.F.N.; Chan, F.H.W.; Ng, W.C.; Yuen, K.Y. The Association between Methicillin Resistant Staphylococcus aureus Colonization and Mortality in Chinese Nursing Home Older Adults: A 2-Year Prospective Cohort. J. Am. Med. Dir. Assoc. 2015, 16, 796-797. [CrossRef] [PubMed]

96. Cheng, V.C.; Tai, J.W.; Wong, Z.S.; Chen, J.H.; Pan, K.B.; Hai, Y.; Ng, W.-C.; Chow, D.M.; Yau, M.C.; Chan, J.F.; et al. Transmission of methicillin-resistant staphylococcus aureus in the long term care facilities in Hong Kong. BMC Infect. Dis. 2013, $13,1-205$. [CrossRef]

97. McKinnell, J.A.; Miller, L.G.; Singh, R.; Kleinman, K.; Peterson, E.M.; Evans, K.D.; Dutciuc, T.D.; Heim, L.; Gombosev, A.; Estevez, M.; et al. Prevalence of and Factors Associated With Multidrug Resistant Organism (MDRO) Colonization in 3 Nursing Homes. Infect. Control Hosp. Epidemiol. 2016, 37, 1485-1488. [CrossRef] [PubMed]

98. O'Sullivan, N.; Keane, C. Risk factors for colonization with methicillin-resistant Staphylococcus aureus among nursing home residents. J. Hosp. Infect. 2000, 45, 206-210. [CrossRef] 
99. Eveillard, M.; LaFargue, S.; Guet, L.; Mangeol, A.; Piquet, J.; Quenon, J.-L.; Fauvelle, F. Association between Institutionalization and Carriage of Multiresistant Bacteria in the Elderly at the Time of Admission to a General Hospital. Eur. J. Clin. Microbiol. Infect. Dis. 1999, 18, 133-136. [CrossRef]

100. Dandachi, I.; Sokhn, E.S.; Najem, E.; Azar, E.; Daoud, Z. Carriage of beta-lactamase-producing Enterobacteriaceae among nursing home residents in north Lebanon. Int. J. Infect. Dis. 2016, 45, 24-31. [CrossRef]

101. Van Der Donk, C.; Schols, J.; Driessen, C.; Hagenouw, R.; Meulendijks, A.; Stobberingh, E. Prevalence and Spread of Multidrug Resistant Escherichia coli Isolates Among Nursing Home Residents in the Southern Part of the Netherlands. J. Am. Med. Dir. Assoc. 2013, 14, 199-203. [CrossRef] [PubMed]

102. Wiener, J.; Quinn, J.P.; Bradford, P.A.; Goering, R.; Nathan, C.; Bush, K.; Weinstein, R.A. Multiple Antibiotic-Resistant Klebsiella and Escherichia coli in Nursing Homes. JAMA 1999, 281, 517-523. [CrossRef] [PubMed]

103. Birgand, G.; Hayatgheib, N.; Bémer, P.; Guilloteau, V.; Legeay, C.; Perron, S.; Chapelet, G.; Corvec, S.; Bourigault, C.; Batard, E.; et al. Multi-drug-resistant Enterobacteriacae carriage in highly exposed nursing homes: Prevalence in western France. J. Hosp. Infect. 2017, 97, 258-259. [CrossRef] [PubMed]

104. Cochard, H.; Aubier, B.; Quentin, R.; Van Der Mee-Marquet, N.; Du Centre, R.D.H. Extended-Spectrum $\beta$-Lactamase-Producing Enterobacteriaceae in French Nursing Homes: An Association between High Carriage Rate among Residents, Environmental Contamination, Poor Conformity with Good Hygiene Practice, and Putative Resident-to-Resident Transmission. Infect. Control Hosp. Epidemiol. 2014, 35, 384-389. [CrossRef]

105. Leitner, E.; Zechner, E.; Ullrich, E.; Zarfel, G.; Luxner, J.; Pux, C.; Pichler, G.; Schippinger, W.; Krause, R.; Zollner-Schwetz, I. Low prevalence of colonization with multidrug-resistant gram-negative bacteria in long-term care facilities in Graz, Austria. Am. J. Infect. Control. 2018, 46, 76-80. [CrossRef]

106. Stuart, R.L.; Kotsanas, D.; Webb, B.; Vandergraaf, S.; Gillespie, E.E.; Hogg, G.G.; Korman, T. Prevalence of antimicrobial-resistant organisms in residential aged care facilities. Med. J. Aust. 2011, 195, 530-533. [CrossRef] [PubMed]

107. Thibaut, S.; Caillon, J.; Marquet, A.; Grandjean, G.; Potel, G.; Ballereau, F.; Microbiology Laboratories of the MedQual Network. Epidemiology of third-generation cephalosporin-resistant community-acquired Enterobacteria isolated from elderly patients. Méd. Mal. Infect. 2014, 44, 57-62. [CrossRef] [PubMed]

108. Rodrigues, C.; Machado, E.; Fernandes, S.; Peixe, L.; Novais, Â. Different Escherichia coli B2-ST131 clades (B and C) producing extended-spectrum $\beta$-lactamases (ESBL) colonizing residents of Portuguese nursing homes. Epidemiol. Infect. 2017, 145, 3303-3306. [CrossRef]

109. Terveer, E.; Fallon, M.; Kraakman, M.; Ormond, A.; Fitzpatrick, M.; Caljouw, M.; Martin, A.; Van Dorp, S.; Wong, M.; Kuijper, E. Corrigendum to "Spread of ESBL-producing Escherichia coli in nursing home residents in Ireland and the Netherlands may reflect infrastructural differences" [J Hosp Infect 103 (2019) 160-164]. J. Hosp. Infect. 2020, 103, 160-164. [CrossRef]

110. Valenza, G.; Nickel, S.; Pfeifer, Y.; Pietsch, M.; Voigtländer, E.; Lehner-Reindl, V.; Höller, C. Prevalence and genetic diversity of extended-spectrum $\beta$-lactamase (ESBL)-producing Escherichia coli in nursing homes in Bavaria, Germany. Veter-Microbiol. 2017, 200, 138-141. [CrossRef]

111. Jallad, M.A.; Naoufal, R.; Irani, J.; Azar, E. Extended Spectrum Beta-Lactamase Carriage State among Elderly Nursing Home Residents in Beirut. Sci. World J. 2015, 2015, 1-7. [CrossRef]

112. Yamamoto, Y.; Luvsansharav, U.-O.; Hirai, I.; Niki, M.; Nakata, A.; Yoshinaga, A.; Matsuura, N.; Kawakami, F. Fecal carriage of CTX-M $\beta$-lactamase-producing Enterobacteriaceae in nursing homes in the Kinki region of Japan. Infect. Drug Resist. 2013, 6, 67-70. [CrossRef] [PubMed]

113. Gorrie, C.L.; Mirceta, M.; Wick, R.R.; Judd, L.M.; Wyres, K.L.; Thomson, N.R.; Strugnell, R.A.; Pratt, N.F.; Garlick, J.S.; Watson, K.M.; et al. Antimicrobial-Resistant Klebsiella pneumoniae Carriage and Infection in Specialized Geriatric Care Wards Linked to Acquisition in the Referring Hospital. Clin. Infect. Dis. 2018, 67, 161-170. [CrossRef]

114. Pulcini, C.; Clerc-Urmes, I.; Attinsounon, C.A.; Fougnot, S.; Thilly, N. Antibiotic resistance of Enterobacteriaceae causing urinary tract infections in elderly patients living in the community and in the nursing home: A retrospective observational study. $J$. Antimicrob. Chemother. 2018, 74, 775-781. [CrossRef] [PubMed]

115. Hagel, S.; Makarewicz, O.; Hartung, A.; Weiß, D.; Stein, C.; Brandt, C.; Schumacher, U.; Ehricht, R.; Patchev, V.; Pletz, M.W. ESBL colonization and acquisition in a hospital population: The molecular epidemiology and transmission of resistance genes. PLoS ONE 2019, 14, e0208505. [CrossRef]

116. Rooney, P.J.; O’Leary, M.C.; Loughrey, A.C.; McCalmont, M.; Smyth, B.; Donaghy, P.; Badri, M.; Woodford, N.; Karisik, E.; Livermore, D.M. Nursing homes as a reservoir of extended-spectrum -lactamase (ESBL)-producing ciprofloxacin-resistant Escherichia coli. J. Antimicrob. Chemother. 2009, 64, 635-641. [CrossRef]

117. Blom, A.; Ahl, J.; Månsson, F.; Resman, F.; Tham, J. The prevalence of ESBL-producing Enterobacteriaceae in a nursing home setting compared with elderly living at home: A cross-sectional comparison. BMC Infect. Dis. 2016, 16, 111. [CrossRef] [PubMed]

118. Broussier, M.; Gbaguidi-Haoré, H.; Rachidi-Berjamy, F.; Bertrand, X.; Slekovec, C. Prevalence, genetic diversity of and factors associated with ESBL-producing Enterobacterales carriage in residents of French nursing homes. J. Hosp. Infect. 2020, 104, 469-475. [CrossRef]

119. Willemsen, I.; Nelson, J.; Hendriks, Y.; Mulders, A.; Verhoeff, S.; Mulder, P.; Roosendaal, R.; Van Der Zwaluw, K.; Verhulst, C.; Bergh, M.K.-V.D.; et al. Extensive Dissemination of Extended Spectrum $\beta$-Lactamase-Producing Enterobacteriaceae in a Dutch Nursing Home. Infect. Control Hosp. Epidemiol. 2015, 36, 394-400. [CrossRef] 
120. Overdevest, I.; Haverkate, M.; Veenemans, J.; Hendriks, Y.; Verhulst, C.; Mulders, A.; Couprie, W.; Bootsma, M.; Johnson, J.; Kluytmans, J. Prolonged colonisation with Escherichia coli O25:ST131 versus other extended-spectrum beta-lactamase-producing E. coli in a long-term care facility with high endemic level of rectal colonisation, the Netherlands, 2013 to 2014 . Eurosurveillance 2016, 21, 30376. [CrossRef]

121. Arvand, M.; Moser, V.; Pfeifer, Y. Prevalence of extended-spectrum- $\beta$-lactamase-producing Escherichia coli and spread of the epidemic clonal lineage ST131 in nursing homes in Hesse, Germany. J. Antimicrob. Chemother. 2013, 68, 2686-2688. [CrossRef]

122. Lautenbach, E.; Han, J.; Santana, E.; Tolomeo, P.; Bilker, W.B.; Maslow, J. Colonization with Extended-Spectrum $\beta$-LactamaseProducingEscherichia coliandKlebsiellaSpecies in Long-Term Care Facility Residents. Infect. Control Hosp. Epidemiol. 2012, 33, 302-304. [CrossRef]

123. Van Der Mee-Marquet, N.; Savoyen, P.; Domelier-Valentin, A.-S.; Mourens, C.; Quentin, R.; Réseau des Hygiénistes du Centre Study Group. CTX-M-Type Fluoroquinolone-Resistant Escherichia coli: Analysis of the Colonization of Residents and Inanimate Surfaces 1 Year after a First Case of Urinary Tract Infection at a Nursing Home in France. Infect. Control Hosp. Epidemiol. 2010, 31, 968-970. [CrossRef]

124. Bertrand, X.; Amara, M.; Sauget, M.; Clément, M.-C.; Talon, D.; Domelier-Valentin, A.-S.; Quentin, R.; van der Mee-Marquet, N. Extended-spectrum beta-lactamase-producing Enterobacteriacae: Unexpected low prevalence of carriage in elderly French residents. Age Ageing 2012, 41, 233-237. [CrossRef]

125. Etherton-Beer, C.D.; Inglis, T.; Waterer, G. Prevalence of oropharyngeal antibiotic-resistant flora among residents of aged care facilities: A pilot study. Respirology 2015, 20, 1139-1141. [CrossRef] [PubMed]

126. Benenson, S.; Cohen, M.J.; Block, C.; Stern, S.; Weiss, Y.; Moses, A.E.; JIRMI Group. Vancomycin-Resistant Enterococci in Long-Term Care Facilities. Infect. Control Hosp. Epidemiol. 2009, 30, 786-789. [CrossRef] [PubMed]

127. Elizaga, M.L.; Weinstein, R.A.; Hayden, M.K. Patients in Long-Term Care Facilities: A Reservoir for Vancomycin-Resistant Enterococci. Clin. Infect. Dis. 2002, 34, 441-446. [CrossRef]

128. Padiglione, A.A.; Grabsch, E.; Wolfe, R.; Gibson, K.; Grayson, M.L. The Prevalence of Fecal Colonization With VRE Among Residents of Long-Term-Care Facilities in Melbourne, Australia. Infect. Control Hosp. Epidemiol. 2001, 22, 576-578. [CrossRef] [PubMed]

129. Silverblatt, F.J.; Tibert, C.; Mikolich, D.; Blazek-D'Arezzo, J.; Alves, J.; Tack, M.; Agatiello, P. Preventing the Spread of VancomycinResistant Enterococci in a Long-Term Care Facility. J. Am. Geriatr. Soc. 2000, 48, 1211-1215. [CrossRef]

130. Cunha, C.; Kassakian, S.Z.; Chan, R.; Tenover, F.C.; Ziakas, P.; Chapin, K.C.; Mermel, L.A. Screening of nursing home residents for colonization with carbapenem-resistant Enterobacteriaceae admitted to acute care hospitals: Incidence and risk factors. Am. J. Infect. Control. 2016, 44, 126-130. [CrossRef]

131. Prasad, N.; Labaze, G.; Kopacz, J.; Chwa, S.; Platis, D.; Pan, C.X.; Russo, D.; LaBombardi, V.J.; Osorio, G.; Pollack, S.; et al. Asymptomatic rectal colonization with carbapenem-resistant Enterobacteriaceae and Clostridium difficile among residents of a long-term care facility in New York City. Am. J. Infect. Control. 2016, 44, 525-532. [CrossRef]

132. Ben-David, D.; Masarwa, S.; Navon-Venezia, S.; Mishali, H.; Fridental, I.; Rubinovitch, B.; Smollan, G.; Carmeli, Y.; Schwaber, M.J.; Israel PACF CRKP (Post-Acute-Care Facility Carbapenem-Resistant Klebsiella pneumoniae) Working Group. CarbapenemResistant Klebsiella pneumoniaein Post-Acute-Care Facilities in Israel. Infect. Control Hosp. Epidemiol. 2011, 32, 845-853. [CrossRef] [PubMed]

133. Prabaker, K.; Lin, M.Y.; McNally, M.; Cherabuddi, K.; Ahmed, S.; Norris, A.; Lolans, K.; Odeh, R.; Chundi, V.; Weinstein, R.A.; et al. Transfer from High-Acuity Long-Term Care Facilities Is Associated with Carriage ofKlebsiella pneumoniaeCarbapenemaseProducingEnterobacteriaceae: A Multihospital Study. Infect. Control Hosp. Epidemiol. 2012, 33, 1193-1199. [CrossRef]

134. Reuben, J.; Donegan, N.; Wortmann, G.; DeBiasi, R.; Song, X.; Kumar, P.; McFadden, M.; Clagon, S.; Mirdamadi, J.; White, D.; et al. Healthcare Antibiotic Resistance Prevalence-DC (HARP-DC): A Regional Prevalence Assessment of Carbapenem-Resistant Enterobacteriaceae (CRE) in Healthcare Facilities in Washington, District of Columbia. Infect. Control Hosp. Epidemiol. 2017, 38, 921-929. [CrossRef] [PubMed]

135. Leitner, E.; Schreiner, E.; Neuhold, M.; Bozic, M.; Pux, C.; Pichler, G.; Schippinger, W.; Steinmetz, I.; Krause, R.; Zollner-Schwetz, I. Low prevalence of Clostridium difficile colonization in patients in long-term care facilities in Graz, Austria: A point-prevalence study. Am. J. Infect. Control. 2020, 48, 1144-1147. [CrossRef] [PubMed]

136. Rodriguez, C.; Taminiau, B.; Korsak, N.; Avesani, V.; Van Broeck, J.; Brach, P.; Delmée, M.; Daube, G. Longitudinal survey of Clostridium difficile presence and gut microbiota composition in a Belgian nursing home. BMC Microbiol. 2016, 16, 1-12. [CrossRef] [PubMed]

137. Walker, K.J.; Gilliland, S.S.; Vance-Bryan, K.; Moody, J.A.; Larsson, A.J.; Rotschafer, J.C.; Guay, D.R.P. Clostridium difficileColonization in Residents of Long-Term Care Facilities: Prevalence and Risk Factors. J. Am. Geriatr. Soc. 1993, 41, 940-946. [CrossRef] [PubMed]

138. Thomas, D.R.; Bennett, R.G.; Laughon, B.E.; Iii, W.B.G.; Bartlett, J.G. Postantibiotic Colonization withClostridium difficilein Nursing Home Patients. J. Am. Geriatr. Soc. 1990, 38, 415-420. [CrossRef] [PubMed]

139. Riggs, M.M.; Sethi, A.K.; Zabarsky, T.F.; Eckstein, E.C.; Jump, R.L.P.; Donskey, C.J. Asymptomatic Carriers Are a Potential Source for Transmission of Epidemic and Nonepidemic Clostridium difficile Strains among Long-Term Care Facility Residents. Clin. Infect. Dis. 2007, 45, 992-998. [CrossRef] 
140. Arvand, M.; Moser, V.; Schwehn, C.; Bettge-Weller, G.; Hensgens, M.P.; Kuijper, E.J. High Prevalence of Clostridium difficile Colonization among Nursing Home Residents in Hesse, Germany. PLoS ONE 2012, 7, e30183. [CrossRef]

141. Mortensen, E.; Trivedi, K.K.; Rosenberg, J.; Cody, S.H.; Long, J.; Jensen, B.J.; Vugia, D.J. Multidrug-Resistant Acinetobacter baumannii Infection, Colonization, and Transmission Related to a Long-Term Care Facility Providing Subacute Care. Infect. Control Hosp. Epidemiol. 2014, 35, 406-411. [CrossRef] [PubMed]

142. O'Fallon, E.; Kandell, R.; Schreiber, R.; D'Agata, E.M.C. Acquisition of Multidrug-Resistant Gram-Negative Bacteria: Incidence and Risk Factors within a Long-Term Care Population. Infect. Control Hosp. Epidemiol. 2010, 31, 1148-1153. [CrossRef] [PubMed]

143. Kahvecioglu, D.; Ramiah, K.; Mcmaughan, D.; Garfinkel, S.; McSorley, V.; Nguyen, Q.N.; Yang, M.; Pugliese, C.; Mehr, D.; Phillips, C.D. Multidrug-Resistant Organism Infections in US Nursing Homes: A National Study of Prevalence, Onset, and Transmission across Care Settings, October 1, 2010-December 31, 2011. Infect. Control Hosp. Epidemiol. 2014, 35, S48-S55. [CrossRef] [PubMed]

144. D'Agata, E.M.C.; Habtemariam, D.; Mitchell, S. Multidrug-Resistant Gram-Negative Bacteria: Inter- and Intradissemination Among Nursing Homes of Residents With Advanced Dementia. Infect. Control Hosp. Epidemiol. 2015, 36, 930-935. [CrossRef]

145. Mody, L.; Krein, S.L.; Saint, S.K.; Min, L.C.; Montoya, A.; Lansing, B.; McNamara, S.E.; Symons, K.; Fisch, J.; Koo, E.; et al. A Targeted Infection Prevention Intervention in Nursing Home Residents With Indwelling Devices. JAMA Intern. Med. 2015, 175, 714-723. [CrossRef] [PubMed]

146. Ziakas, P.D.; Zacharioudakis, I.M.; Zervou, F.N.; Grigoras, C.; Pliakos, E.E.; Mylonakis, E. Asymptomatic Carriers of Toxigenic C. difficile in Long-Term Care Facilities: A Meta-Analysis of Prevalence and Risk Factors. PLoS ONE 2015, 10, e0117195. [CrossRef]

147. Donskey, C.J.; Kundrapu, S.; Deshpande, A. Colonization Versus Carriage of Clostridium difficile. Infect. Dis. Clin. N. Am. 2015, 29, 13-28. [CrossRef] [PubMed]

148. Simor, A.E.; Bradley, S.F.; Strausbaugh, L.J.; Crossley, K.; Nicolle, L.E. SHEA Long-Term-Care Committee Clostridium difficilein Long-Term-Care Facilities for the Elderly. Infect. Control Hosp. Epidemiol. 2002, 23, 696-703. [CrossRef]

149. Thompson, G.; Shindruk, C.L.; Adekoya, A.A.; Demczuk, L.; McClement, S. Meanings of 'centredness' in long-term care facilities: A scoping review protocol. BMJ Open 2018, 8, e022498. [CrossRef] 